\title{
Influence of Prior Strain History on the Tensile Properties and Structures of High-Purity Copper
}

\author{
William D. Jenkins and Thomas G. Digges
}

\begin{abstract}
Tensile tests were made at room temperature on oxygen-free high-conductivity (OFHC) copper initially as annealed, as cold-drawn different amounts, and as prestrained in creep at $110^{\circ}, 250^{\circ}$, and $300^{\circ} \mathrm{F}$.

The shape of the true stress-strain curves obtained on copper cold-drawn 34-, 40-, and 70 percent reduction in area indicate a strain aging effect in the specimens when subjected to stresses in the vicinity of the maximum load. This phenomenon of strain aging is usually more closely associated with alloys of the ferrous type than with a high-purity nonferrous metal. The present results show that the strength, ductility, and hardness of the copper is markedly affected by its prior strain history. The test conditions are correlated with the tensile properties, hardness, necking characteristics, formation of microcracks, and substructures.
\end{abstract}

\section{Introduction}

The tensile and other properties at room temperature of both annealed and cold-drawn high-purity copper were determined as a part of the Bureau's research investigations of the mechanism of creep and of the effects of subzero temperatures on the mechanical properties of metals and alloys. The creep behavior of this same lot of copper as annealed and as cold-drawn 40-percent reduction in area and the influence of low temperatures on the true stressstrain relation in tension of the annealed copper have been discussed in previous publications [1, 2, $\left.3{ }^{1}\right]$ The resistance to creep and to fracture at moderately elevated temperatures was materially increased by cold-drawing the copper, but this superiority was accomplished by a decrease in ductility. The strain history of the copper also affected the degree of dissociation of the parent grains into subsize grains during creep and the type of fracture. However, the strength in tension of the annealed copper increased continuously with a decrease in temperature to $-320^{\circ} \mathrm{F}$ without any impairment of its ductility.

The present tests were made to evaluate the effects of prestraining different amounts in creep under tension at $110^{\circ}, 250^{\circ}$, and $300^{\circ} \mathrm{F}$ and of cold-drawing on the tensile properties at room temperature and on the hardness and structures produced in the fractured specimens. The straining treatments used prior to testing the specimens in tension at room temperature are summarized in table 1.

\section{Material and Procedures}

All the specimens were prepared from $13 / 16$ - or 7/8-in. diameter bars processed from one lot of oxygen-free high-conductivity (OFHC) copper containing $99.99+$ percent of copper. The four bars

TABLE 1. Strain history of specimens prior to testing in tension at room temperature and reference to the figures used in the text for summarizing the test data

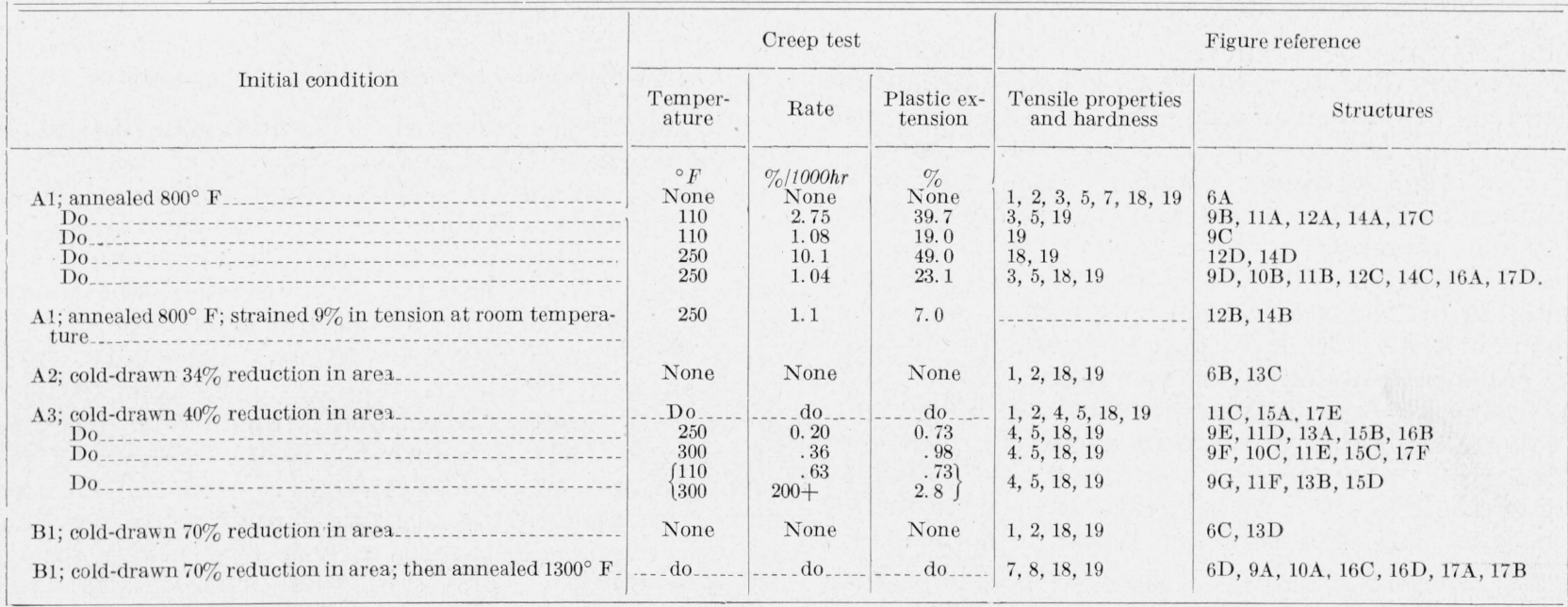

Figures in brackets indicate the literature references at the end of this paper.

$217025-52-3$ 
used were procured in conditions as follows:

A. Bright annealed at $800^{\circ} \mathrm{F}$ for $1 \mathrm{hr}$ :
1. As annealed
$0.025-\mathrm{mm}$
average grain diameter.
2. Cold-drawn 34-percent reduction in area.
3. Cold-drawn 40-percent reduction in area.

B. Bright annealed at $1150^{\circ} \mathrm{F}$ for $50 \mathrm{~min}(0.045-\mathrm{mm}$ average grain diameter):
1. Cold-drawn
70-percent reduction in area.

Tensile specimens, 0.505 in. in diameter with 2-in. gage length, were prepared from the above bars. In addition, a portion of the bar cold-drawn $7 \mathrm{C}$ percent (condition B1) was reannealed in the laboratory at $1,300^{\circ} \mathrm{F}$ in air for $1 \mathrm{hr}$, thereby producing an average grain diameter of $0.120 \mathrm{~mm}$, before preparing the tensile specimen. Some tensile specimens prepared from the bars as annealed at $800^{\circ} \mathrm{F}$ and as cold-drawn 40 percent (conditions $\mathrm{A} 1$ and 3, respectively) were strained in creep at various temperatures before fracturing them in tension at room temperature.

The tensile tests were made at room temperature at a rate of approximately 1-percent reduction of area per minute. A micrometer was used to follow the change in diameter of the tensile specimen during the testing. Simultaneous observations were made of the minimum diameters and loads.

Two flats were prepared approximately 0.2 in. apart, diametrically opposite, symmetrical to and parallel to the longitudinal axis of the fractured specimen. Rockwell hardness (F scale, 60-kg load, 1/16-in.-diameter ball) readings were made at various points along the center line of each flat. Specimens were also cut from the bar cold-drawn 70 percent for use in determining the effect of annealing temperature on its grain size and hardness.

\section{Results and Discussion}

\subsection{Effect of prestraining on tensile properties}

\section{a. Cold-drawing at room temperature}

The relations between true stress and the total true strain ${ }^{2}$ (due to cold-drawing and tension) for specimens of copper as annealed and as cold-drawn different amounts are shown in figure 1 . The true stress at the beginning of plastic deformation in tension, and the true stress and true strain at maximum load increased with an increase in the amount of cold-drawing. The values for true stress at the beginning of fracture in each specimen as annealed, or as cold-drawn 40 or 70 percent, were nearly alike but cracking started at a somewhat lower value of stress in the specimen cold-drawn only 34 percent. However, the total true strain at the beginning of fracture of this specimen was about the same as that of the specimen as annealed or as cold-drawn 40 percent. In this series of tests the total strain

\footnotetext{
2 "True strain" is defined as the natural logarithm of the ratio of the initial cross-sectional area $\left(A_{0}\right)$ of the specimen to its current minimum cross-sectional area $(A)$.
}

at the beginning of fracture attained a maximum in the specimen cold-drawn 70 percent.

The observed differences in the relative positions and slopes of the true stress-strain curves can be partly ascribed to variations in the stress system during plastic deformation in tension in addition to variations in the degree of strain hardening induced by cold-drawing. For the annealed specimen, the deformation was essentially by unidirectional tension for stresses up to the maximum load. As the specimen began to neck at this point, further deformation was under a triaxial stress system. This triaxiality results in modifying the position of the curve to higher values of stresses for similar strains than would have been the case had deformation to complete fracture been under a unidirectional system. Similarly, necking began at maximum load in each of the cold-drawn specimens and thereafter deformation was by triaxiality. The effect of triaxiality, however, varied with the amount of coldworking and thereby affected the stress-strain relationship. Furthermore, some triaxiality also existed during cold-drawing, and this is a factor that would be expected to decrease the value of the stress at the maximum load. Obviously, some strain hardening occurred during cold-drawing, and the capacity of the copper to further strain hardening was thereby reduced.

The effect of cold-drawing on the hardness and tensile properties of the copper is shown by the results given in figure 2 . The yield strength, tensile strength and hardness increased at a decreasing rate, with an increase in the amount of cold-drawing. The plastic extension in tension, however, was materially decreased by cold-drawing, but the magnitudes of the decrease in plastic extension and of the increase in hardness were not significantly affected by varying the degree of cold-working from 34 to 70 percent. For example, the plastic extension at maximum load did not exceed 1 percent in any of the cold-drawn specimens but was about 30 percent in the annealed specimen. Thus the improvements in strengths and in hardness by cold-drawing the copper were accompanied by an impairment in its plastic extension in tension at room temperature.

\section{b. Cold-working in creep at different temperatures}

(1) Initially as annealed. The influence of straining specimens of the annealed copper in creep at $110^{\circ}$ and $250^{\circ} \mathrm{F}$ on the true stress-true strain relation at room temperature is shown by the curves in figure 3 . The curves for the specimens prestrained in creep fall somewhat below that of the annealed specimen. However, the true stress at maximum load (point M) of the annealed copper was increased slightly by prestraining 23.1 percent in creep at $250^{\circ} \mathrm{F}$ and further increased in another specimen strained 39.7 percent in creep at $110^{\circ} \mathrm{F}$ before fracturing in tension at room temperature. The curves for stresses from the maximum load to the beginning of fracture for the two specimens prestrained in creep were nearly alike, but the specimen prestrained at $250^{\circ} \mathrm{F}$ began to fracture at considerably lower stress and strain than 
did the specimen prestrained in creep at $110^{\circ} \mathrm{F}$. The stress required to initiate fracture in the latter specimen was only slightly less than that of the annealed specimen and the corresponding total strains at this point were nearly alike for the two specimens. Although the specimen prestrained at $110^{\circ} \mathrm{F}$ was strained into the third stage of creep, the curve indicates that its mode of deformation in tension at room temperature was similar to that of the annealed specimen; however, straining the specimen into the second stage of creep at $250^{\circ} \mathrm{F}$ was believed to be sufficient to initiate cracks of submicroscopic dimensions, and these possibly are partly responsible for its restricted ductility at room temperature. These assumptions are supported by the evidence obtained from a metallographic examination of the fractured specimens. In the specimen prestrained 23.1 percent at $250^{\circ} \mathrm{F}$, numerous cracks were observed in the region adjacent to and at some distance (unnecked portion of the specimen) from complete fracture (fig. 12C), whereas in the specimens prestrained 39.7 percent at $110^{\circ} \mathrm{F}$, the microcracking was confined to the region of complete fracture (fig. 12A); the mode of fracture of the latter specimen was similar to that previously described for an annealed specimen [1].

Straining the specimen 23.1 percent in creep at $250^{\circ} \mathrm{F}$ also lowered appreciably both the true stress and the strain at complete fracture in relation to those of the specimens as annealed or as prestrained 39.7 percent at $110^{\circ} \mathrm{F}$.

(2) Initially as annealed and then cold-drawn 40 percent. The effect of prestraining the cold-drawn copper in creep at different temperatures on some tensile properties at room temperature is shown in figure 4. The strain in creep at moderately elevated temperatures resulted in some modification of the positions of the true stress-strain curves at room temperature for values of true stresses below 65,000 psi. In this range of stresses, the curves for the specimens prestrained in creep fall somewhat below that of the specimen as cold-drawn. At true stresses of 65,000 psi, or higher, the true stress-strain curve of the specimen strained 0.73 percent at $110^{\circ} \mathrm{F}$, and then 2.8 percent at $300^{\circ} \mathrm{F}$ nearly coincided with that of the specimen as cold-drawn. The values for true stress at maximum load, and true stress and strain at the beginning of fracture were also similar for these two specimens, but the values for stress and strain at complete fracture were lower in the specimen strained in creep.

Prestraining a specimen 0.73 percent at $250^{\circ} \mathrm{F}$ and another specimen 0.98 percent at $300^{\circ} \mathrm{F}$ lowered somewhat the true stresses at maximum load and appreciably decreased the true stresses and strains at the beginning and at complete fracture. The decrease in stresses and strains at fracture was considerably more pronounced in the specimen prestrained at $300^{\circ} \mathrm{F}$ than in the specimen prestrained at $250^{\circ} \mathrm{F}$. The values of stress and strain at complete fracture of the former specimen were lower than the corresponding values at the beginning of fracture for the latter specimen. This deterioration, as shown in the tensile properties at room temperature, is believed to be due partly to the initiation of cracks of submicroscopic or possibly microscopic dimension (fig. 15, C) by the presence of tensile stresses induced in creep. Moreover, the tendency towards brittle fracture was increased by increasing the temperature of the creep test from $250^{\circ}$ to $300^{\circ} \mathrm{F}$ and adjusting the stresses to produced strain rates of 0.2 to 0.4 percent $/ 1,000 \mathrm{hr}$. (figs. 11, D and E).

The true stress-strain curves at small strains of the annealed and cold-drawn copper specimens are reproduced on an enlarged scale in figure 5. Thereversal of curvature of the curve for the colddrawn specimen not prestrained in creep indicates that an aging effect took place subsequent to the cold-drawing operation (fig. 5, A). This initial effect is in contrast to the recovery behavior usually associated with nonferrous metals such as aluminum [4] after cold-extending and appears to be more closely associated with the strain-aging behavior of alloys of the ferrous type [5]. The residual stresses due to cold-drawing and aging of the copper are partly relieved after the specimen has been deformed slightly past its maximum load. This caused a lowering of the true stress values over a limited range of increasing strains. This effect of aging is less pronounced but still present, as is shown by the positions of the true stress-strain curves for the two cold-drawn specimens prestrained in creep at $250^{\circ}$ and $300^{\circ} \mathrm{F}$ to true strains of less than 0.01 . The relief of the causes of the aging phenomenon appears to be more pronounced for the specimen prestrained at the higher temperature even though the creep strain was slightly less. The true stress-strain values for the specimen prestrained in creep at $110^{\circ}$ and at $300^{\circ} \mathrm{F}$ to a higher strain value show a pronounced recovery characteristic, as evidenced by a decrease in true stress values at small strains. This effect, however, was followed by rapid strain-hardening in contrast to the other two specimens whose rate of strain-hardening was approximately equal to that of the cold-drawn specimen in the region from the inflection range up to a true strain value of about 0.15. A relief of internal stress followed by rapid strain-hardening is also shown by the position of the true stress-strain curve for the annealed specimen that was prestrained in creep at $250^{\circ} \mathrm{F}$, whereas aging appeared to predominate for the specimen prestrained in creep at the lower temperature (fig. 5, B). The recovery phenomenon associated with straining in creep above the temperature that was used in the tensile tests is further illustrated by the values labeled $e_{1}, e_{2}$, etc. in figure 5. The broken lines intersecting the true stress-strain curves at $e_{1}$, $\mathrm{e}_{3}, \mathrm{e}_{5}, \ldots$ are in each case the extrapolation of the linear portion of the corresponding true stress-strain curve for a specimen prestrained in creep. The points $\mathrm{e}_{2}, \mathrm{e}_{4}, \mathrm{e}_{6}$ represent the strains actually obtained at the corresponding stress. In spite of the fact that the true stress-strain curve was lowered considerably for the specimens prestrained at $110^{\circ}$ and $300^{\circ} \mathrm{F}$ to about 0.09 strain (fig. $5, \mathrm{~A}$ ), the attainment of the stress at $e_{10}$, corresponding to the stress of the 
cold-drawn copper at $e_{9}$, took place at a much smaller change in strain than similar attainments for the other two specimens $\left(\mathrm{e}_{8}\right.$ and $\mathrm{e}_{7}$, and $\mathrm{e}_{6}$ and $\left.\mathrm{e}_{5}\right)$. However, prestraining in creep to different strains at different temperatures had no appreciable effect on the initial recovery characteristics of the annealed specimens when the relationships are evaluated by this means. A comparison of the properties at small strains with the true stress-strain relationships, shown by figures 3 and 4 , indicates that the instantaneous strain state of the material does not necessarily predict the subsequent flow properties.

Burghoff and Blank [6] extended cold-drawn specimens of oxygen-iree copper in creep at $300^{\circ}$ and $400^{\circ} \mathrm{F}$ prior to testing in tension at room temperature. The tensile strength was materially decreased and the elongation was increased in specimens initially cold-drawn 84 percent after exposure of $6,500 \mathrm{hr}$ at $300^{\circ}$ or $400^{\circ} \mathrm{F}$, with zero or small stresses. Partial or complete recrystallization occurred in the specimens exposed at $300^{\circ}$ or $400^{\circ} \mathrm{F}$.

Some strain-aging effects, associated with OFHC copper have recently been discussed by Lubahn [7]. From results of room-temperature tensile tests, interrupted by various heat treatments, he suggests that the aging process may be associated with (a) yieldpoint phenomenon, (b) increase in flow stress, (c) discontinuous yielding, and (d) abnormally low rate sensitivity.

\subsection{Effect of grain size}

A change from 0.025 to $0.120 \mathrm{~mm}$ in the average diameter of the grains in the annealed copper (fig. 6, $A$ and D) caused a decrease in the yield strength $(0.2 \%$ offset) from about 11,000 to $6,000 \mathrm{psi}$, a slight lowering of the true stress-strain curve for stresses in the region of strain below 0.15 , and a decrease in the stess and the strain at the beginning of fracture (fig. 7). However, the tensile strength and the strain at this stress were not affected by the increase in grain size.

The effect of annealing temperature (1 hr at temperature) on the grain size and hardness of the copper cold-drawn 70 percent from an average grain diameter of $0.045 \mathrm{~mm}$ (condition B1), is shown in figure 8 . Increasing the annealing temperature from $800^{\circ}$ to $1,100^{\circ} \mathrm{F}$ resulted in a slight increase in grain size. The size of the grains continued to increase gradually as the temperature was further increased to $1,200^{\circ} \mathrm{F}$ and then increased markedly at an annealing temperature of $1,300^{\circ} \mathbf{F}$. This grain growth and recovery was accompanied by a corresponding decrease in hardness of the recrystallized specimens.

The features observed in necking and fracturing the specimens in tension at room temperature can be conveniently classified into three groups, as illustrated in figure $10, \mathrm{~A}, \mathrm{~B}$, and $\mathrm{C}$. All the specimens fractured at room temperature were of the ductile, or fibrous, type, but the values for strain and reduction of area varied appreciably with the prior-strain history. Roughing of the surface, necking down to nearly a point and then fracturing at approximately right angles to the longitudinal axis of the specimen (fig. 10, A) were characteristics of all specimens not strained prior to testing in tension at room temperature. Possibly the relatively large grains contributed to the excessive roughing of the surface in the region of the fracture of this particular specimen. The appearance of the surface at and near the fracture of the specimens prestrained by cold-drawing and in creep is represented by the specimen shown in figure 10, C. Some roughening of the surface is evident in this specimen, but it is considerably less pronounced than that of the specimen not prestrained in creep (fig. 10, A). The fractures of the prestrained specimens were usually in a plane about $45^{\circ}$ to $60^{\circ}$ to the longitudinal axis. No macrocracks were observed in the surfaces near complete fracture of the specimens shown in fig. 10, $\mathrm{A}$ and $\mathrm{C}$, but there was some evidence of their presence in B. Moreover, macrocracks were prominent in an initially annealed specimen after being strained to complete fracture in creep at $300^{\circ} \mathrm{F}$ (figure $10, \mathrm{D}$ ).

An end view of some of the fractured specimens is given in figure 11. The cavities located in the center regions and their relative absence near the outer surface support the belief that cracking was initiated near the axis and the outer surface was the position of final rupture.

\subsection{Effect of prestraining on structures}

\section{a. Necking and fracturing characteristics}

Figures 9, 10, and 11 are photographs of some of the specimens selected as representative of the necking and fracture characteristics as affected by priorstrain history. As all of the specimens showed some necking (fig. 9), it is believed that cracking eventually leading to failure started at the axis of each specimen and progressed outward, and the final fracture was that of the "rim" at the surface. However, the degree of necking and the magnitude of the rim effect of the specimens were influenced by the amount, rate, and temperature of prestraining. For example, an initially annealed specimen prestrained 39.7 percent extension in creep at $110^{\circ} \mathrm{F}$ developed both a relatively pronounced neck (fig. 9, B) and rim (fig. $11, \mathrm{~A})$, whereas the specimen cold-drawn 40-percent reduction of area and then strained in creep only 0.98 percent at $300^{\circ} \mathrm{F}$ developed a relatively small neck (fig. 9, F), a small rim (fig. 10, C and fig. 11, E), and fractured in a relatively brittle manner. As these two specimens were processed from the same lot of copper and tested in tension at room temperature at the same strain rate, the defference in ductility at fracture must be attributed to changes brought about by the different methods of prestraining.

\section{b. Rim formation and microcracks}

The influence of prestraining on the formation of microcracks and the flow characteristics at the rim in the region of complete fracture in tension at room temperature is shown by the photomicrographs of figures 12 and 13. (No microcracks were evident near the surface or axis of the annealed specimens not prestrained in creep.) Furthermore, it was 
possible to strain a specimen at $110^{\circ} \mathrm{F}$ into the third stage of creep without the development of numerous microcracks, except in the vicinity of complete fracture, in subsequent fracturing at room temperature (fig. 12, A). Microcracks were not observed in another specimen (fig. 12, B) prestrained only into the second stage of creep at a somewhat higher temperature $\left(250^{\circ} \mathrm{F}\right)$. However, a general disintegration is shown in two other specimens that were prestrained at $250^{\circ} \mathrm{F}$ into either the second or third stage of creep (fig. 12, C and D). As previously pointed out [2], the presence or absence of microcracks in specimens fractured solely in creep depended upon the initial condition of the copper, the creep rate, temperature, and amount of extension in creep; relatively slow creep rates, high temperatures, and increase in amount of extension into the third stage of creep favored a general disintegration.

Relatively few microcracks are evident near the surface of the copper that was cold-drawn before testing in tension (fig. 13) even when the specimens were prestrained into third stage of creep (fig. 13, A and $\mathrm{B})$. The effect of prestraining at the higher temperature (fig. 13, B) seems to promote a grain recovery effect causing a healing of the broken bonds to take place and thus a restoration of ductility and strength (fig. 4). Limited grain fragmentation and the alinement of the grains in a wavy manner results from cold-drawing the copper 34-percent reduction of area prior to testing in tension (fig. 13, C), whereas further cold-drawing to 70 -percent reduction in area (fig. 13, D) appeared to result in considerable grain fragmentation and an increase in tensile strength and in total ductility at fracture (fig. 1).

\section{c. Microcracks and structures at axis}

Structures at the surface do not necessarily reflect the flow characteristics in the interior of these specimens as the stress systems in these regions are different. However, as shown in figures 14 and 15 , microcracks are evident near the axis of all the specimens that showed the tendency toward crack formation near the surface (figs. 12 and 13). Relatively few cracks are visible in the annealed specimen prestrained at $110^{\circ} \mathrm{F}$ to a large strain (fig. 14, A) or at $250^{\circ} \mathrm{F}$ to a small strain (fig. 14, B). A number of of cracks are evident at the axis of the specimen prestrained in creep into the second stage at $250^{\circ} \mathrm{F}$ with a slow creep rate (fig. $14, \mathrm{C}$ ) and of another specimen prestrained into the third stage of creep at the same temperature with a faster creep rate (fig. $14, \mathrm{D}$ ). However, the contour of the cracks is different, probably due to the different mechanisms of crack nucleation in creep and subsequent growth in the tensile test.

The effect of prior straining on the formation of microcracks at the axis of the cold-drawn copper is shown in figure 15. Some microcracks of elliptical shape are evident in specimens not strained in creep (fig. 15, A), but these are much smaller than the cracks in a specimen prestrained in creep at $250^{\circ} \mathrm{F}$ to a small strain (fig. 15, B). The type of fracture and the shape of the microcracks appear to be affected significantly by raising the creep test temperature (fig. 15, C) without appreciable change in creep rate or in plastic strain. Straining in creep at a higher temperature $\left(300^{\circ} \mathrm{F}\right)$ and at a faster rate after prestraining at $110^{\circ} \mathrm{F}$ to a small strain value seems to cause an effect that is reflected in the absence of microcracks even in the region of complete fracture at room temperature (fig. 15, D).

A further indication of the effects of prior history on the internal structure and the initiation and growth of microcracks is shown in figure 16 . The presence of microcracks in the regions representative of structure at the limit of uniform strain (fig. 16, $A$ and B, several cracks are enclosed in circles) indicates that a partial disintegration was evident throughout these specimens. As no microcracks have been found in any of the copper specimens previously strained into the second stage of creep [1, $2]$, it is believed that the conditions for crack formation are initiated during the second stage of creep, and with a continued straining in tension at room temperature the cracks grow to such a size that the flow properties of the copper are affected. Representative structure in the unnecked portion of the specimens not tested in creep is shown in figure 16 , $C$ and D. No microcracks were evident in this region of either this specimen or of any of the specimens not prestrained under creep conditions. The relative straightness of portions of the twins and the difference in orientation between the twins and the surrounding material (fig. 16, D) indicate that these are annealing twins that were nucleated at a grain boundary (lower arrow) and grew toward another boundary (upper arrow) of the grains. During deformation portions of the annealing twins were bent, thus indicating that they are ductile (fig. 16, C).

\section{d. Substructures}

The effect of prestraining on the formation of substructures is shown in figure 17 . Etch patterns representative of the initially annealed structure are shown in figure $17, \mathrm{~A}$. It has been previously pointed out [8] that the size of these substructures is influenced by the temperature of annealing and that the tendency toward formation of substructures of smaller size during deformation increased with decrease in test temperature and with increase in creep rate $[1,2]$. However, the latter observations were based on tests carried to completion in creep tests only. The present tests show that the sizes of the substructures in the copper were materially reduced by testing in tension at room temperature only (fig. 17, A and B). It is also evident that both the size and distribution of the substructures are affected by the temperature, creep rate, or strain in creep prior to the tensile test (figs. 17, C, D, E, and F). Both high temperatures and slow strain rates appear to increase the tendency toward the formation of a large number of these substructures. 


\subsection{Effect of prestraining on specimen contour and on hardness at room temperature}

The relation of reduction of area to distance from the fractured surface and to hardness at room temperature, of specimens tested in tension at room temperature, as affected by prestraining, is shown in figures 18 and 19. The distribution of ductility as measured by the reduction of area values along the specimen was materially affected by colddrawing the copper prior to testing in tension (fig. 18, A) but increasing the amount of cold-drawing from 34- to 70-percent reduction of area had no appreciable effects on the final contour of the surface of the specimen. Annealing at $1,300^{\circ} \mathrm{F}$ appeared to restore the original necking characteristics so that he curve nearly coincided with the curve obtained with the specimen annealed at $800^{\circ} \mathrm{F}$ (fig. 18, B). However, when specimens cut from the latter bar were strained in creep before the room-temperature tensile test, a more brittle type of fracture, as shown by decrease in sharpness of the neck (fig. 18, C), was obtained. This tendency toward brittle fracture was also evident in the colddrawn specimens after straining in creep (fig. 18, D), and was promoted by an increase in creep temperature or by a decrease in creep rate.

The effect of prestraining on the relation between hardness at room temperature and reduction of area is shown in figure 19. The trend was for the hardness to increase with increase in reduction of area up to values of about 35 percent for the initially cold-drawn and 50 percent for the initially annealed specimens. Thereafter, the hardness either remained constant or decreased with an increase in reduction of area. The specimen initially colddrawn 40 percent (fig. 19, A) had numerous cracks in the region corresponding to 50-percent reduction of area (fig. 15, A). Reannealing at $1,300{ }^{\circ} \mathrm{F}$ after cold-drawing 70 percent caused a lowering of the hardness, at all strains, to values approximately the same as those of the specimen initially annealed at $800^{\circ} \mathrm{F}$ (fig. 19, B). The average grain diameter of the specimen annealed at $1,300^{\circ} \mathrm{F}$ was about five times that of the specimen annealed at $800^{\circ} \mathrm{F}(0.120$ and $.025 \mathrm{~mm}$, respectively). Straining in creep at $110^{\circ} \mathrm{F}$ to an extension of 19 percent had no appreciable effect in lowering the hardnessreduction of area curve of the initially annealed specimens (fig. 19, C). However, the relative positions of the hardness-reduction of area curves and the peak-hardness values were altered by straining in creep at higher temperatures or to higher strain values (fig. 19, C and D). Several factors, such as differences in the stress systems, size and distribution of the microcracks and substructures, appear to influence the hardness values of the copper.

\section{Summary}

Tensile tests were made at room temperature on OFHC copper initially as annealed, as cold-drawn, and as prestrained under creep conditions. Micro- scopic examinations and hardness tests were made at room temperature to ascertain the effects of the prior thermal-strain history on the structure and hardness.

Yield strength, tensile strength, initial hardness, true stress at maximum load, increased with increase in prestraining by cold-drawing; this superiority in the strength and hardness properties was accompanied by a decrease in ductility at maximum load and at fracture.

The general trend was for a decrease in the flow stress, fracture stress, and ductility as the prestraining temperature in creep increased and the creep rate decreased.

Aging, due to prestraining, and recovery were evidenced by the shape of the true stress-strain curves.

The degree of necking and the tendency for the formation of a rim at fracture increased with a decrease in prestraining temperature or with an increase in prestraining rate. However, the tendency for recovery, disintegration by microcracking, and the size of substructure were increased as the prestraining temperature was increased. Microcracking also was increased by decreasing the prestraining rate in creep.

An increase in grain size tended to lower both the hardness and yield strength. The temperature and rate of prestraining also materially affected the hardness.

The authors gratefully acknowledge their indebtedness to C. R. Johnson for his assistance in the test program.

\section{Reterences}

[1] W. D. Jenkins and T. G. Digges, Creep of high-purity copper, J. Research NBS 45, 153 (1950) RP2121.

[2] W. D. Jenkins and T. G. Digges, Creep of annealed and cold-drawn high-purity copper, J. Research NBS 47, 272 (1951) RP2254

[3] G. W. Geil and N. L. Carwile, Tensile properties of copper, nickel, and some copper-nickel alloys at low temperatures, NBS Circular 520 (1952).

[4] W. D. Jenkins, Creep of high-purity aluminum, J. Research, NBS 46, 310 (1951) RP2201.

[5] D. J. McAdam, Jr., G. W. Geil, D. H. Woodard and W. D. Jenkins, Influence of strain aging on the fracture stress of low carbon steel, Trans. AIME 176, 436 (1948).

[6] H. L. Burghoff and A. I. Blank, The creep characteristics of copper and some copper alloys at 300, 400, and $500^{\circ} \mathrm{F}$, Proc. Am. Soc. Testing Materials 47, 725 (1947)

[7] J. D. Lubahn, Strain aging effects, Trans. Am. Soc. Metals 44, 643 (1952).

[8] P. Lacombe and L. Beaujard, The application of etch figures on pure aluminum to the study of some micrographic problems, J. Inst. Metals LXXIV, 1 (1948). 


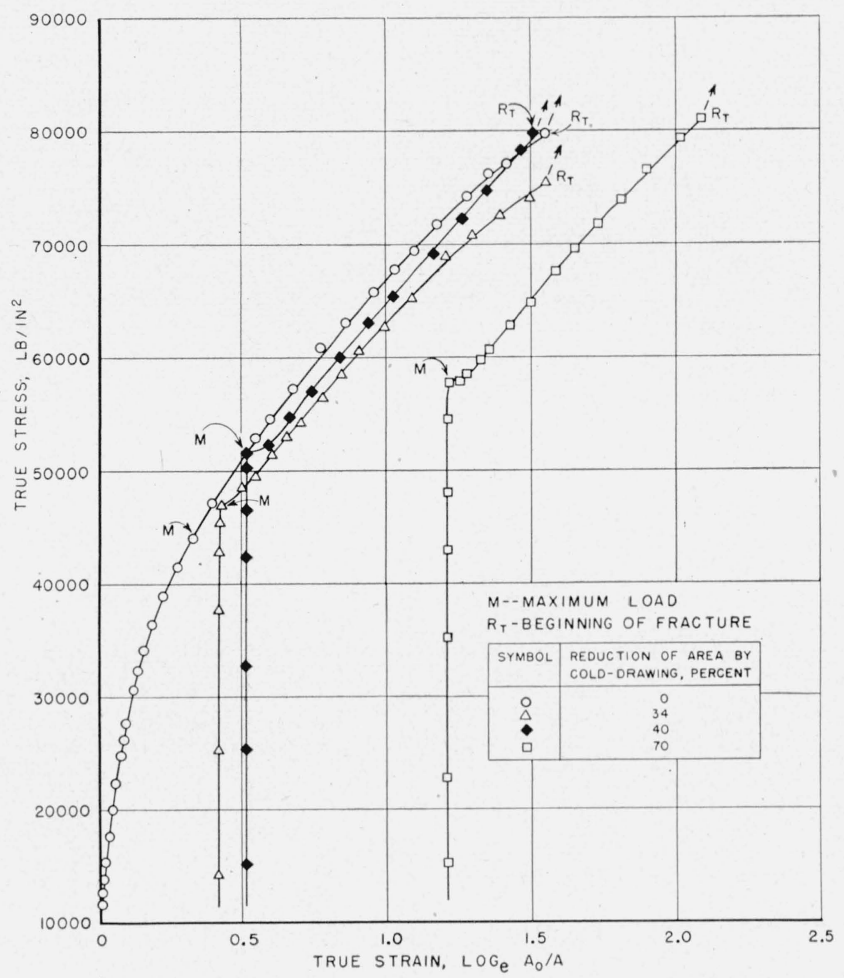

Figure 1. Effect of cold-drawing on the trae stress-strain relation at room temperature of copper.

The strains corresponding to cold-drawing are included in the plotted values.

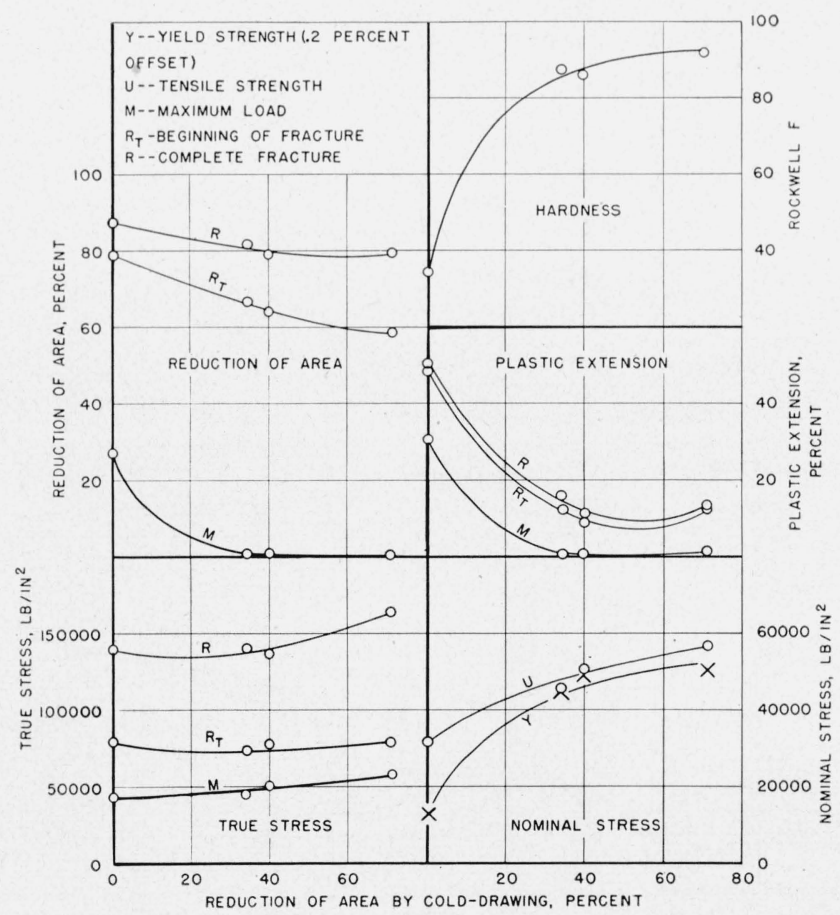

Figure 2. Effect of cold-drawing on the hardness and tensile properties at room temperature of copper.

The hardness tests were made on cross sections of the bars initially as annealed and as cold-drawn. 


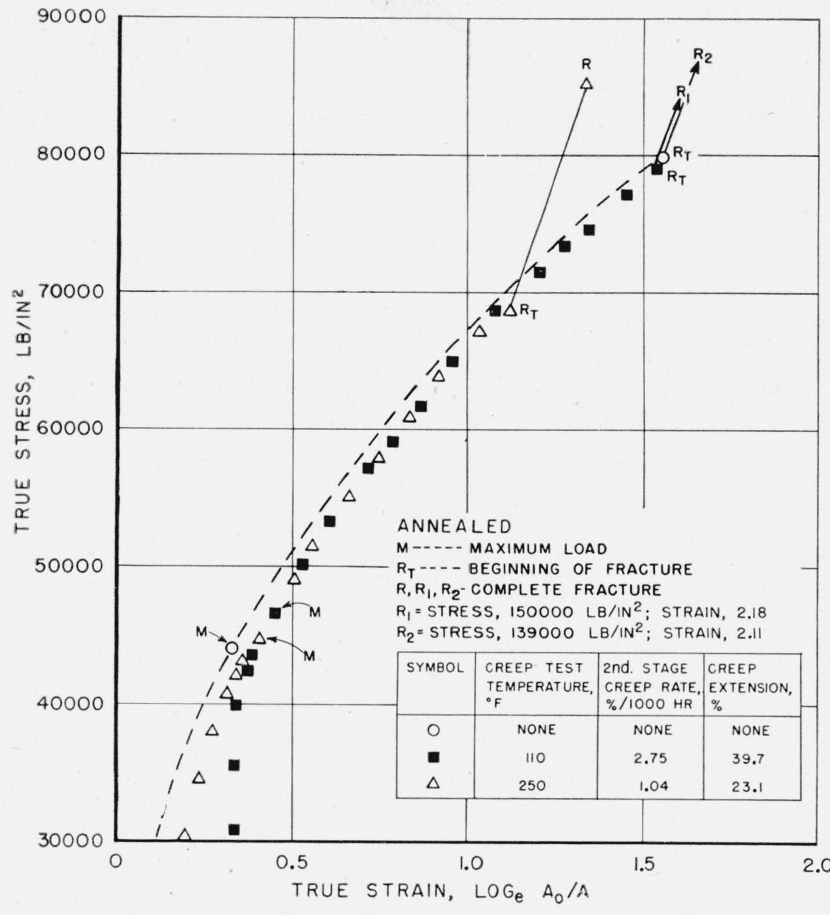

Figure 3. Effect of prestraining in creep on the true stressstrain relation at room temperature of annealed copper.

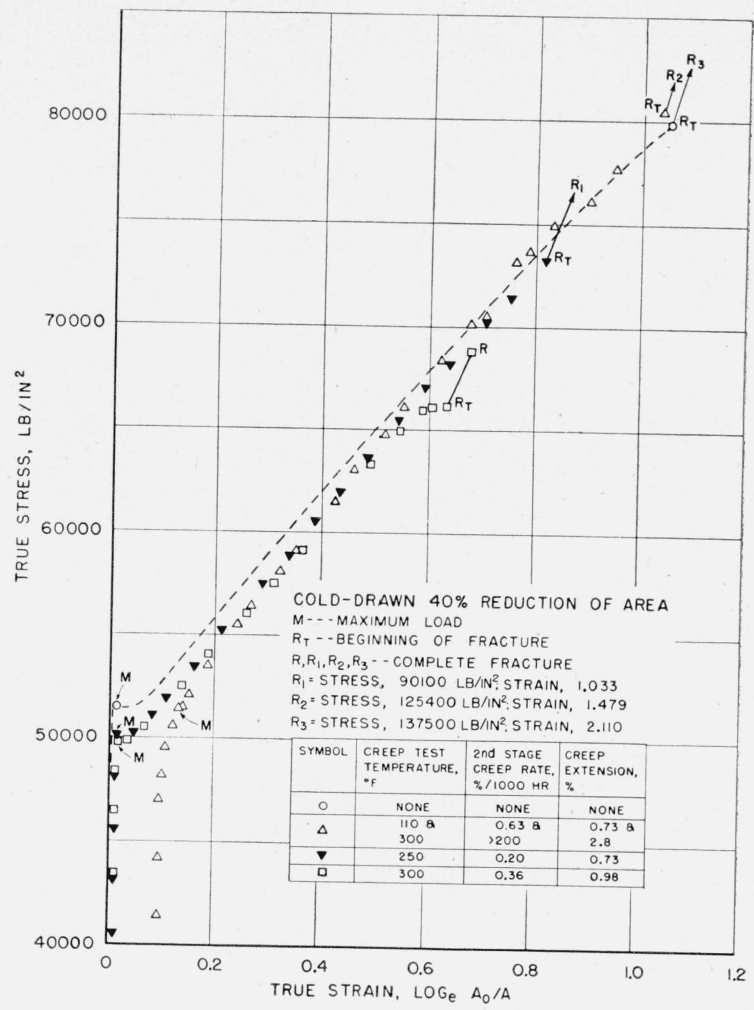

Figure 4. Effect of prestraining in creep on the true stressstrain relation at room temperature of cold-drawn copper.

"The strain corresponding to cold-drawing 40-percent reduction in area is not included in the plotted value.

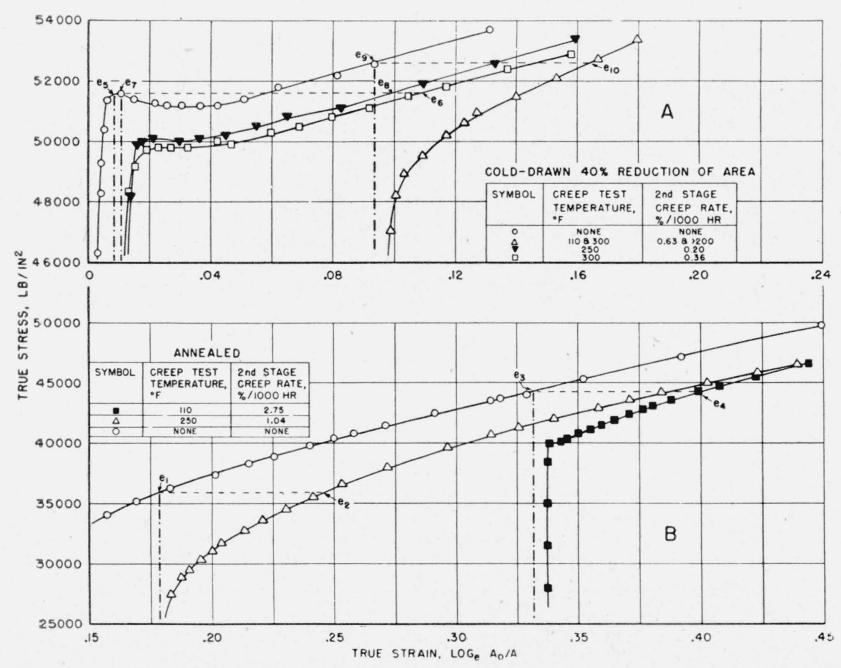

Figure 5. Effect of prestraining in creep on the true stressstrain relation, at small strains, at room temperature, of both cold-drawn and annealed copper. 


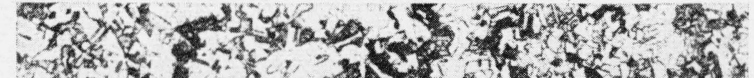

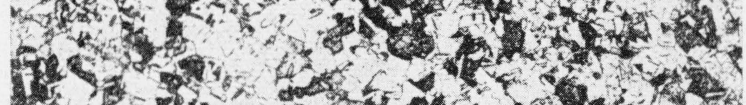

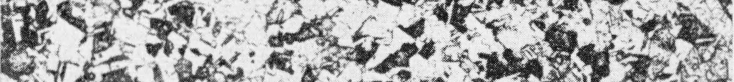

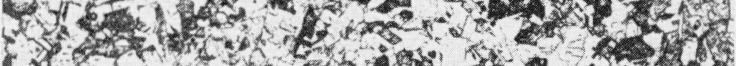

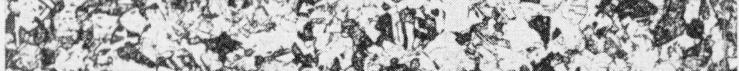
Q1. 2.

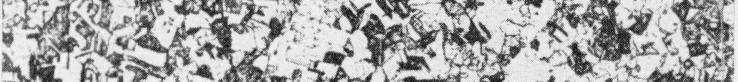
4)

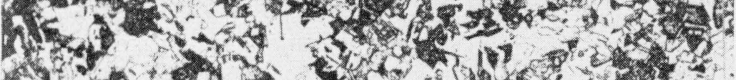

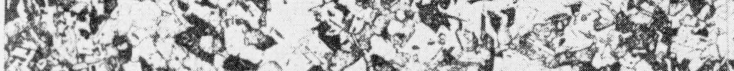

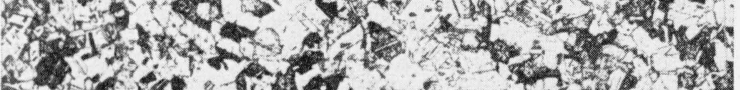

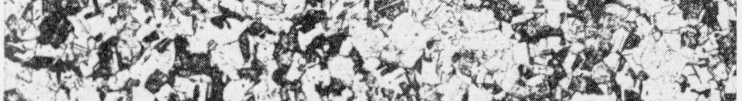

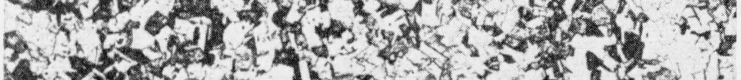
10.

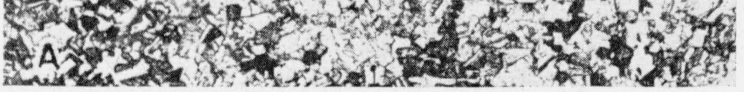

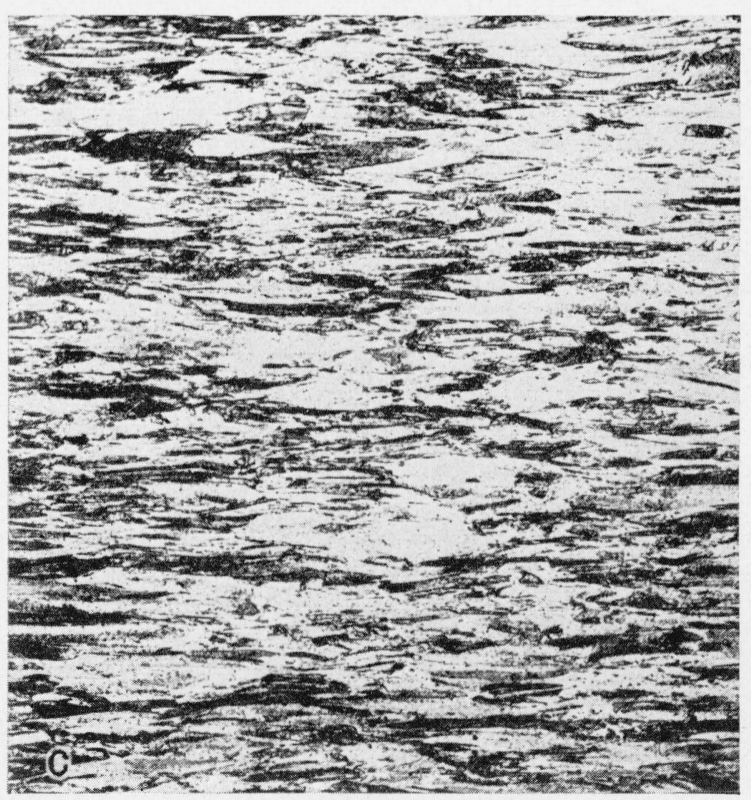

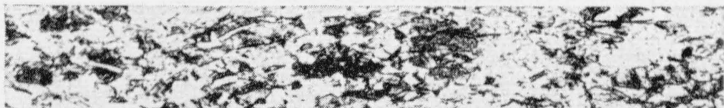

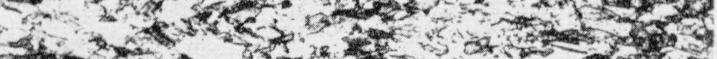

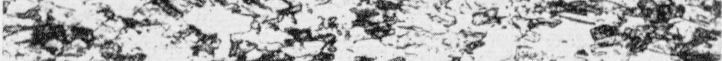

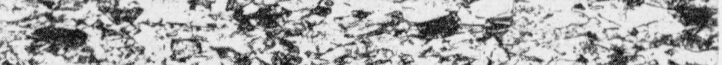

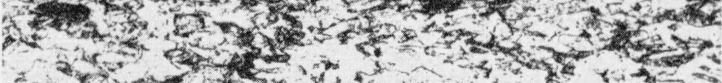

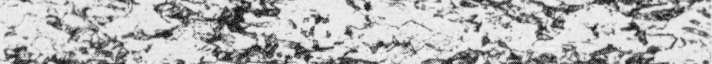

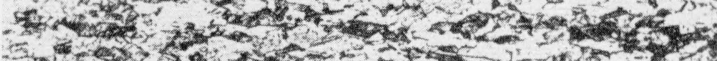

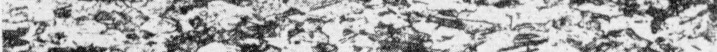

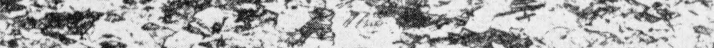

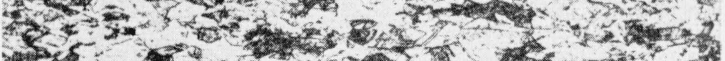

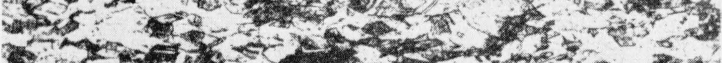

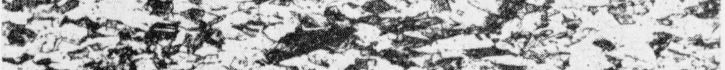

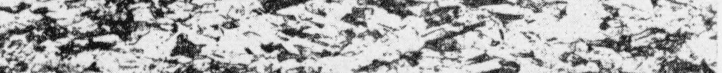

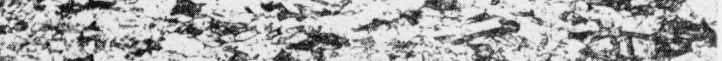

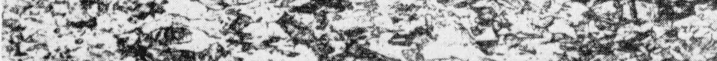

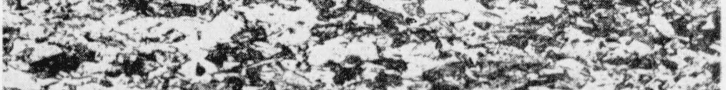

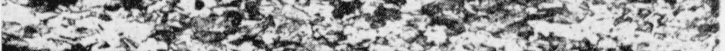

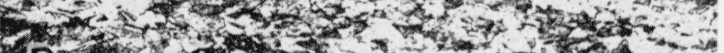
B.

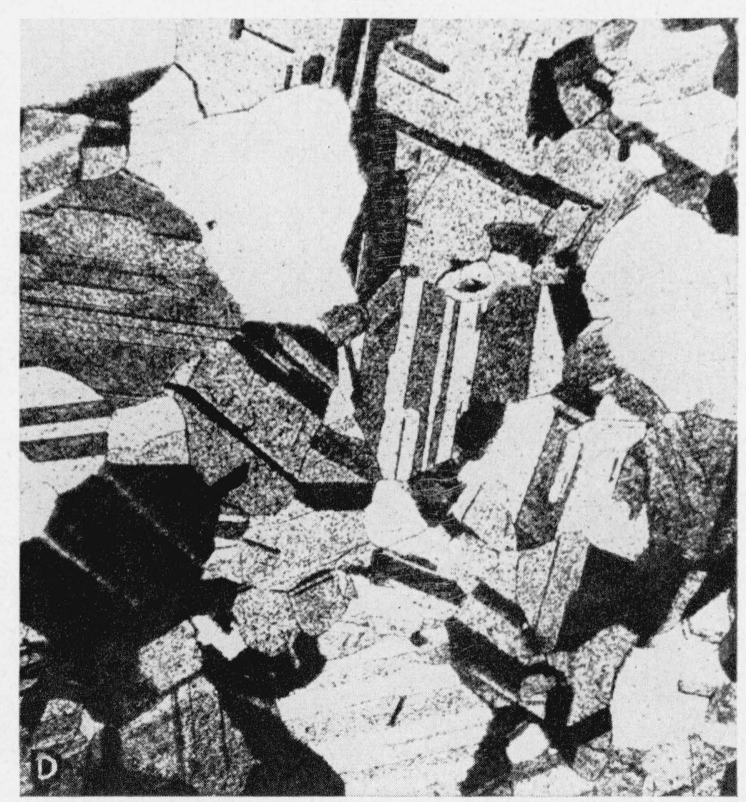

of copper in different initial conditions. diameter. 


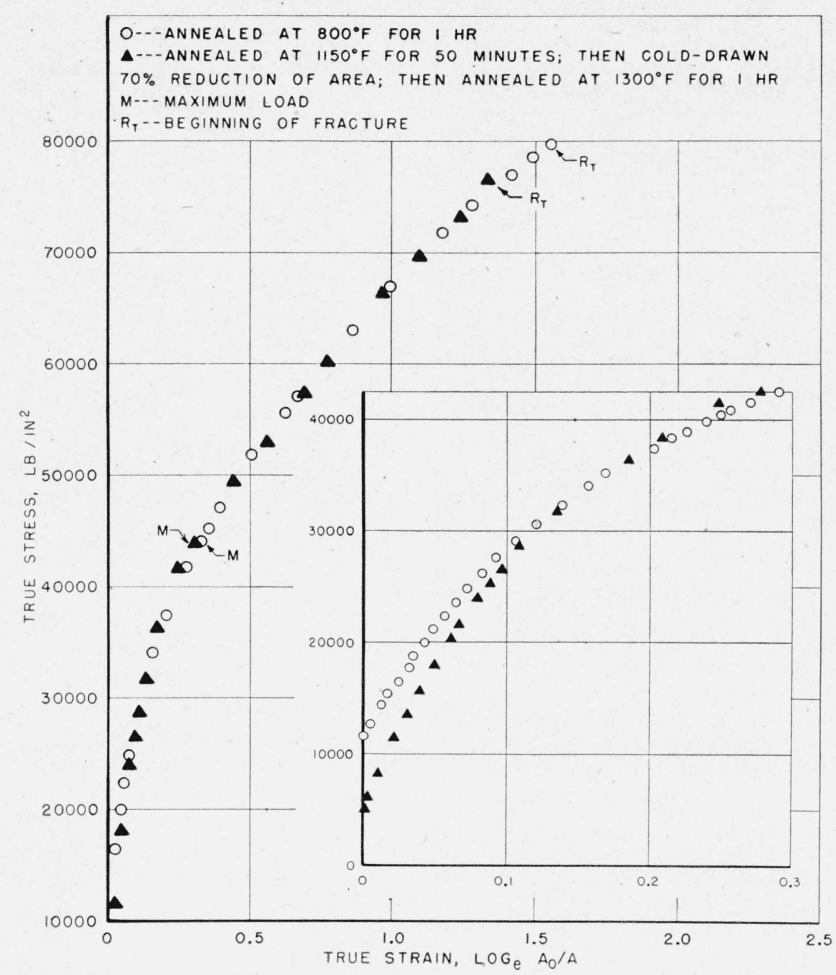

Figure 7. Effect of grain size on the true stress-strain relation at room temperature of annealed copper.

Annealed at $800^{\circ} \mathrm{F}, 0.025 \mathrm{~mm}$ average grain diameter. Annealed at $1,300^{\circ} \mathrm{F}$ $0.120-\mathrm{mm}$ average grain diameter.

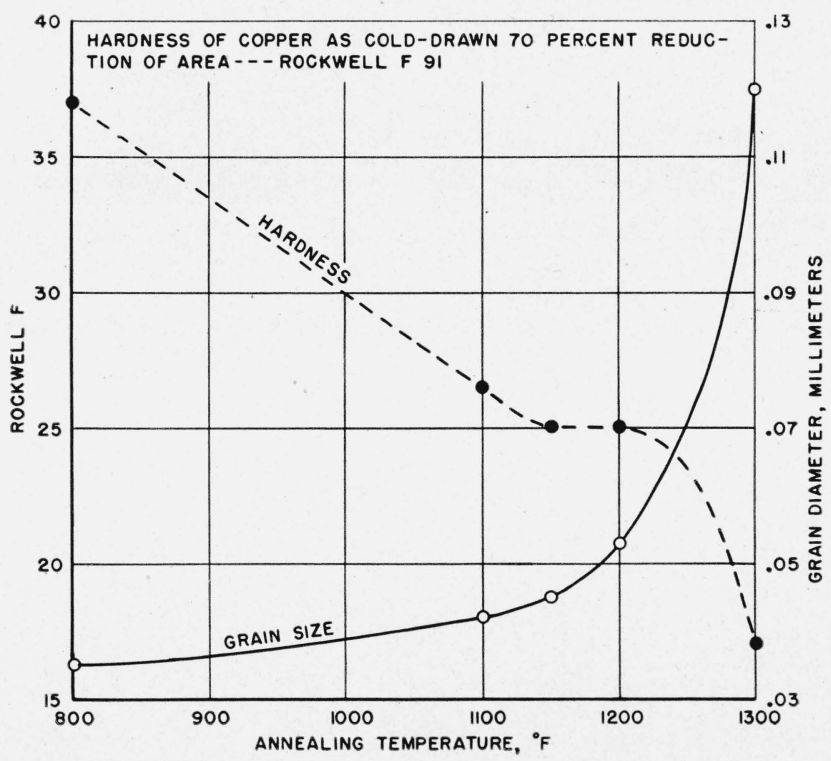

Figure 8. Effect of annealing temperature on the grain size and hardness of cold-drawn copper. 


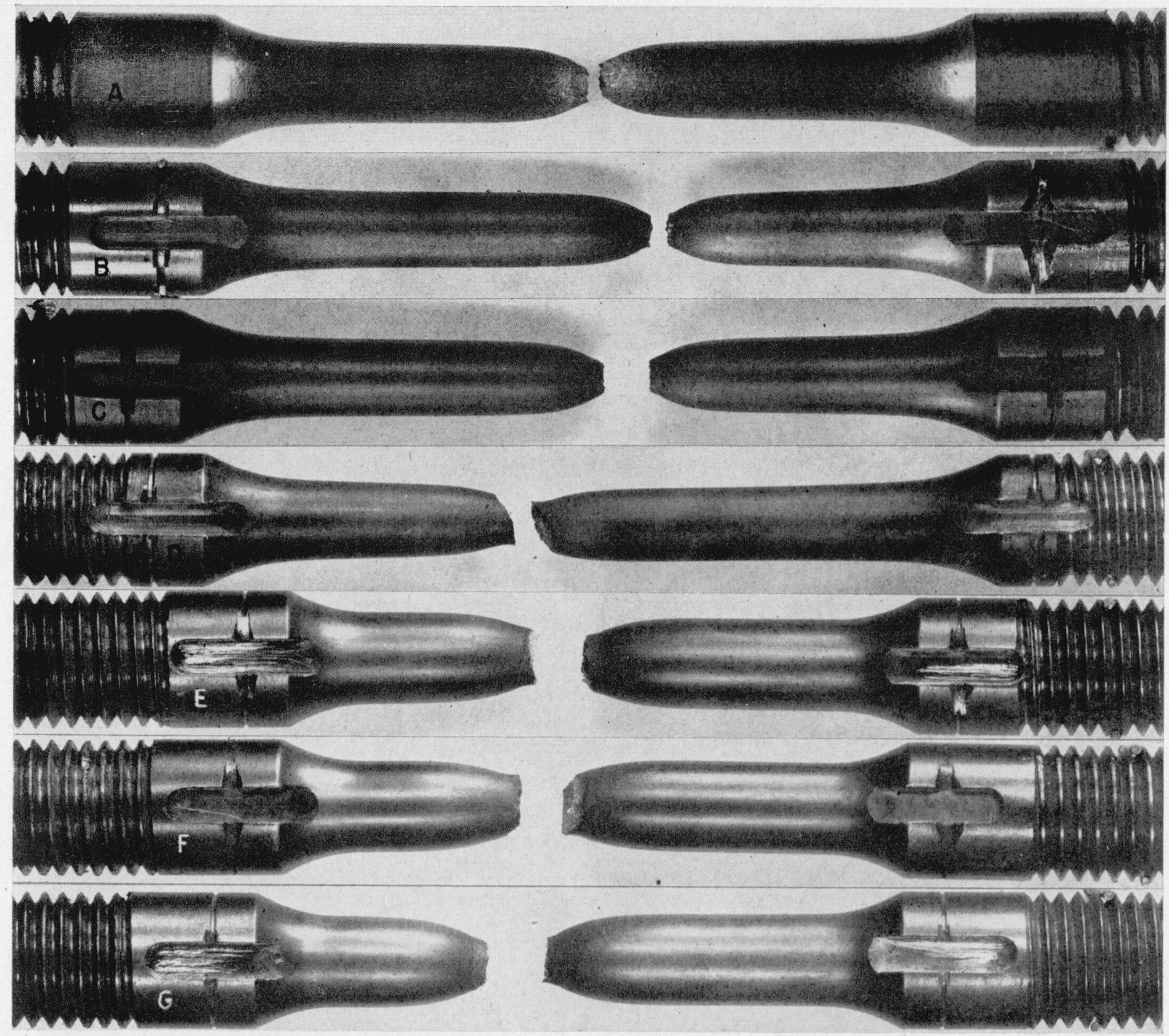

FIGURE 9. Some of the copper specimens after fraciuring at room temperature.

Unetched, $\times 1$.

\begin{tabular}{|c|c|c|c|c|c|}
\hline & \multirow{2}{*}{ Initial condition } & \multicolumn{3}{|c|}{ Creep test } & \multirow{2}{*}{$\begin{array}{l}\text { Truè } \\
\text { strain at } \\
\text { complete } \\
\text { fracture }\end{array}$} \\
\hline & & $\begin{array}{l}\text { Temper- } \\
\text { ature }\end{array}$ & Rate & $\begin{array}{c}\text { Plastic } \\
\text { extension }\end{array}$ & \\
\hline A $\ldots$ & $\begin{array}{l}\text { Cold-drawn } 70 \% ; \text { an- } \\
\text { nealed } 1300^{\circ} \mathrm{F}\end{array}$ & $\begin{array}{l}\circ F \\
\text { None }\end{array}$ & $\begin{array}{l}\% / 1,000 h r \\
\text { None }\end{array}$ & $\begin{array}{c}\% \\
\text { None }\end{array}$ & 1.96 \\
\hline B & Annealed, $800^{\circ} \mathrm{F}$ & 110 & 2. 75 & 39.7 & 2. 18 \\
\hline C- & $\ldots$ do & $\begin{array}{l}110 \\
250\end{array}$ & $\begin{array}{l}1.08 \\
1.04\end{array}$ & $\begin{array}{l}19.0 \\
231\end{array}$ & 1. 94 \\
\hline $\mathrm{E}$. & Cold-drawn, $40 \%$ & 250 & $\begin{array}{l}1.04 \\
0.20\end{array}$ & 0.73 & $\begin{array}{l}1.50 \\
1.03\end{array}$ \\
\hline $\mathrm{F}$ & _._. do & 300 & .36 & .98 & 0.68 \\
\hline $\mathrm{G}_{-.}$ & ...... do $o_{\ldots} \ldots$ & $\left\{\begin{array}{l}110 \\
300\end{array}\right.$ & $200 \dot{+}^{63}$ & $2.83\}$ & 1. 48 \\
\hline
\end{tabular}



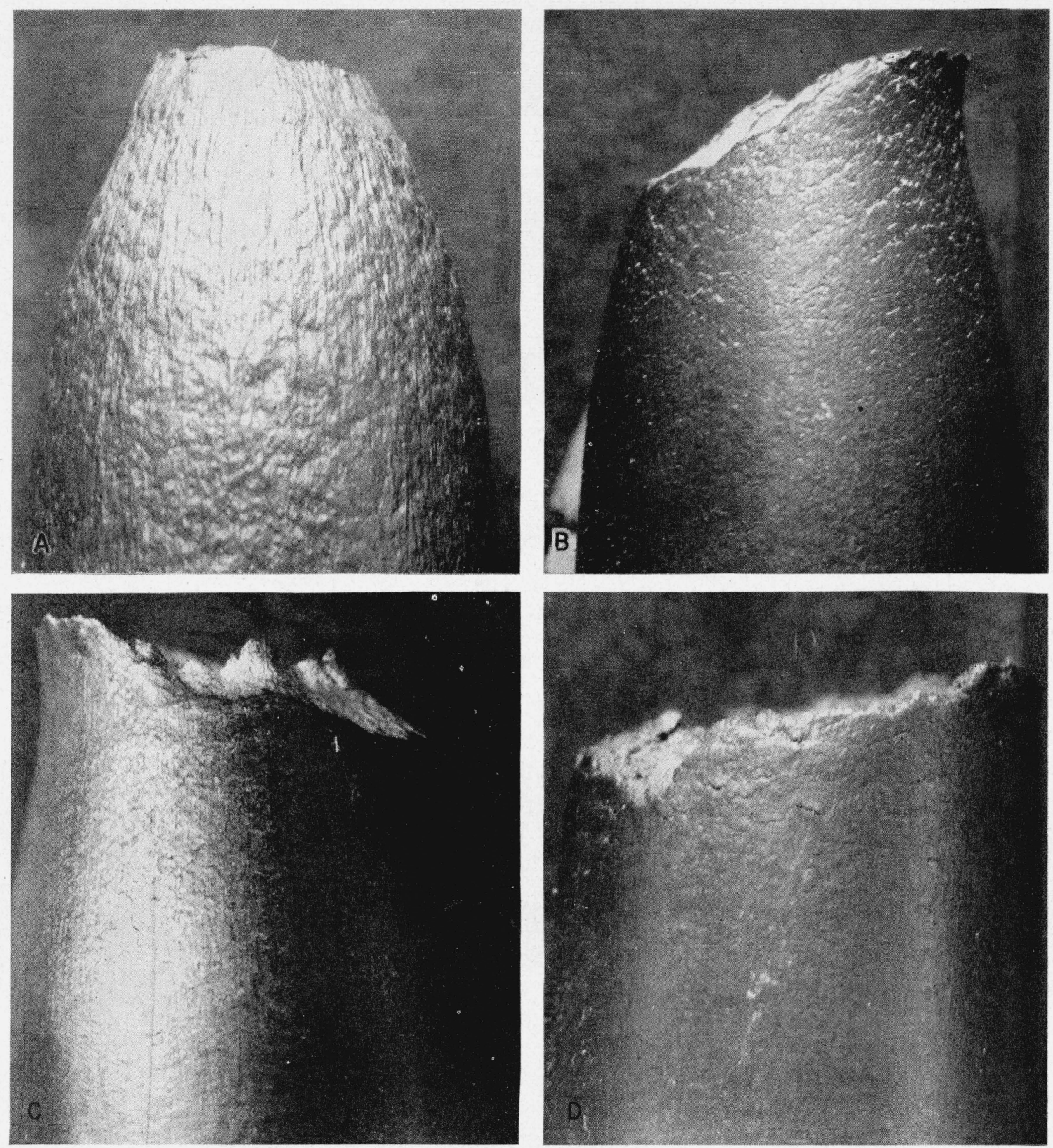

FIGURE 10. Representative copper specimens showing the surface conditions after fracture.

Unetched, $\times 7$.

\begin{tabular}{|c|c|c|c|c|c|}
\hline & \multirow{2}{*}{ Initial condition } & \multicolumn{3}{|c|}{ Creep test } & \multirow{2}{*}{ Remarks } \\
\hline & & $\begin{array}{c}\text { Temper- } \\
\text { ature }\end{array}$ & Rate & $\begin{array}{c}\text { Plastic } \\
\text { ex- } \\
\text { tension }\end{array}$ & \\
\hline $\begin{array}{l}\text { A. } \\
\text { B.- } \\
\text { C.- } \\
\text { D.- }\end{array}$ & $\begin{array}{l}\text { Cold-drawn } 70 \% ; \text { an- } \\
\text { Anealed } 1,300^{\circ} \mathrm{F} \text {. } \\
\text { Annealed } 800^{\circ} \mathrm{F} \\
\text { Cold-drawn } 40 \% \\
\text { Annealed } 800^{\circ} \mathrm{F} \\
\end{array}$ & $\begin{array}{c}{ }^{\circ} \mathrm{F} \\
\text { None } \\
250 \\
300 \\
300\end{array}$ & $\begin{array}{c}\% / 1,000 \\
h r \\
\text { None } \\
\\
1.04 \\
0.36 \\
8.3\end{array}$ & $\begin{array}{c}\% \\
\text { None } \\
23.1 \\
0.98 \\
36.5\end{array}$ & $\begin{array}{l}\text { Fractured at room } \\
\text { temperature. } \\
\text { Do. } \\
\text { Do. } \\
\text { Fractured in creep } \\
\text { at } 300^{\circ} \mathrm{F} \text {. }\end{array}$ \\
\hline
\end{tabular}



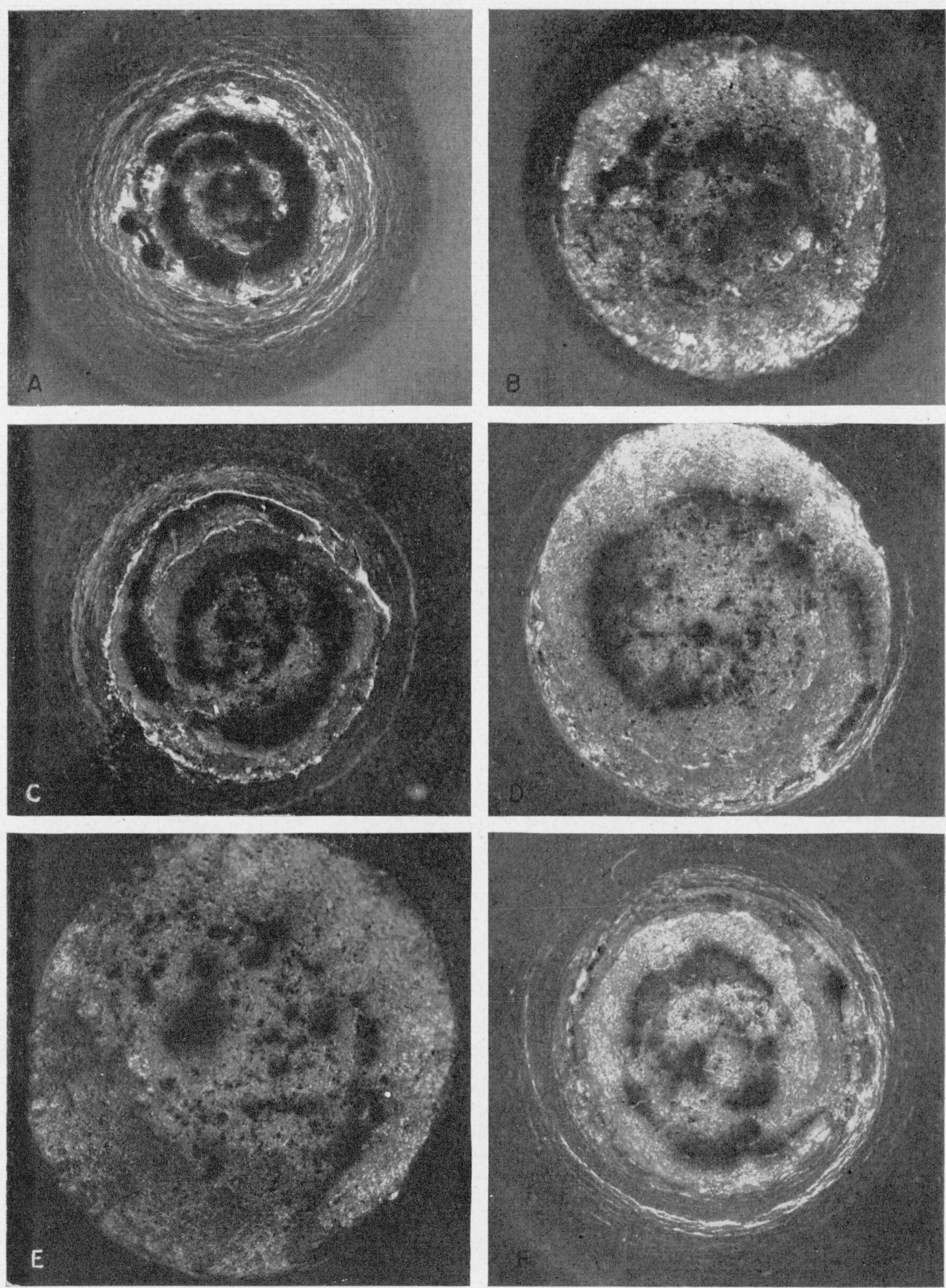

FIGURE 11. Ends of copper specimens after fracturing at room temperature. Unetched, $\times 7$.

\begin{tabular}{|c|c|c|c|c|}
\hline & \multirow{2}{*}{ Initial condition } & \multicolumn{3}{|c|}{ Creep test } \\
\hline & & $\begin{array}{l}\text { Temper- } \\
\text { ature }\end{array}$ & Rate & $\begin{array}{c}\text { Plastic } \\
\text { extension }\end{array}$ \\
\hline $\begin{array}{l}\mathrm{A} \\
\mathrm{B} \\
\mathrm{C} \\
\mathrm{D} \\
\mathrm{E} \\
\mathrm{E} \\
\mathrm{F}\end{array}$ & $\begin{array}{l}\text { Annealed } 800^{\circ} \mathrm{F} \\
\text { Coldo drawn } 40 \% \\
\text { do }\end{array}$ & $\begin{array}{c}{ }^{\circ} F \\
110 \\
250 \\
\text { None } \\
250 \\
300 \\
\left\{\begin{array}{l}110 \\
300\end{array}\right.\end{array}$ & $\begin{array}{c}\% / 1,000 \mathrm{hr} \\
2.75 \\
1.04 \\
\text { None } \\
0.20 \\
.36 \\
200+\end{array}$ & $\begin{array}{c}\% \\
39.7 \\
23.1 \\
\text { None } \\
0.73 \\
.98 \\
.73 \\
2.8\end{array}$ \\
\hline
\end{tabular}



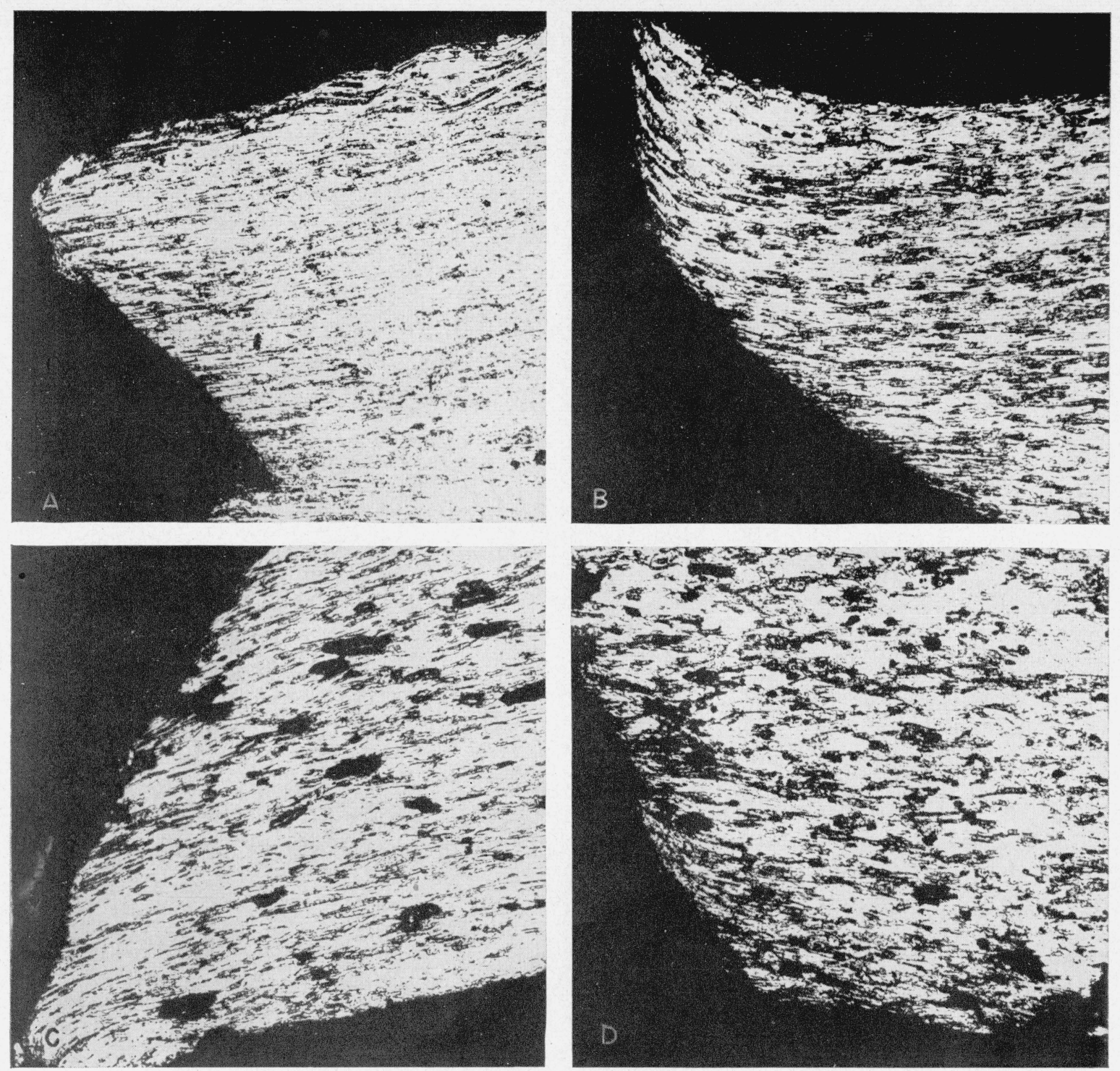

FigURE 12. Structures at the surfaces of specimens of annealed copper fractured in tension at room temperature.

Longitudinal sections at the intersection of the outer (original) and fracture surfaces. Etched in equal parts $\mathrm{NH}_{4} \mathrm{OH}$ and $\mathrm{H}_{2} \mathrm{O}_{2}(3 \%)$. $\times 100$.

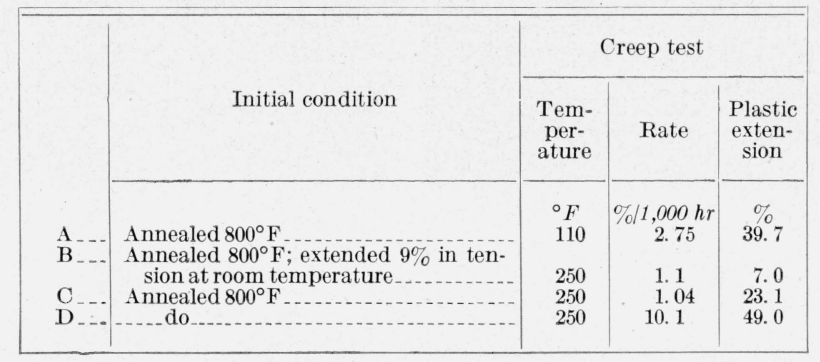



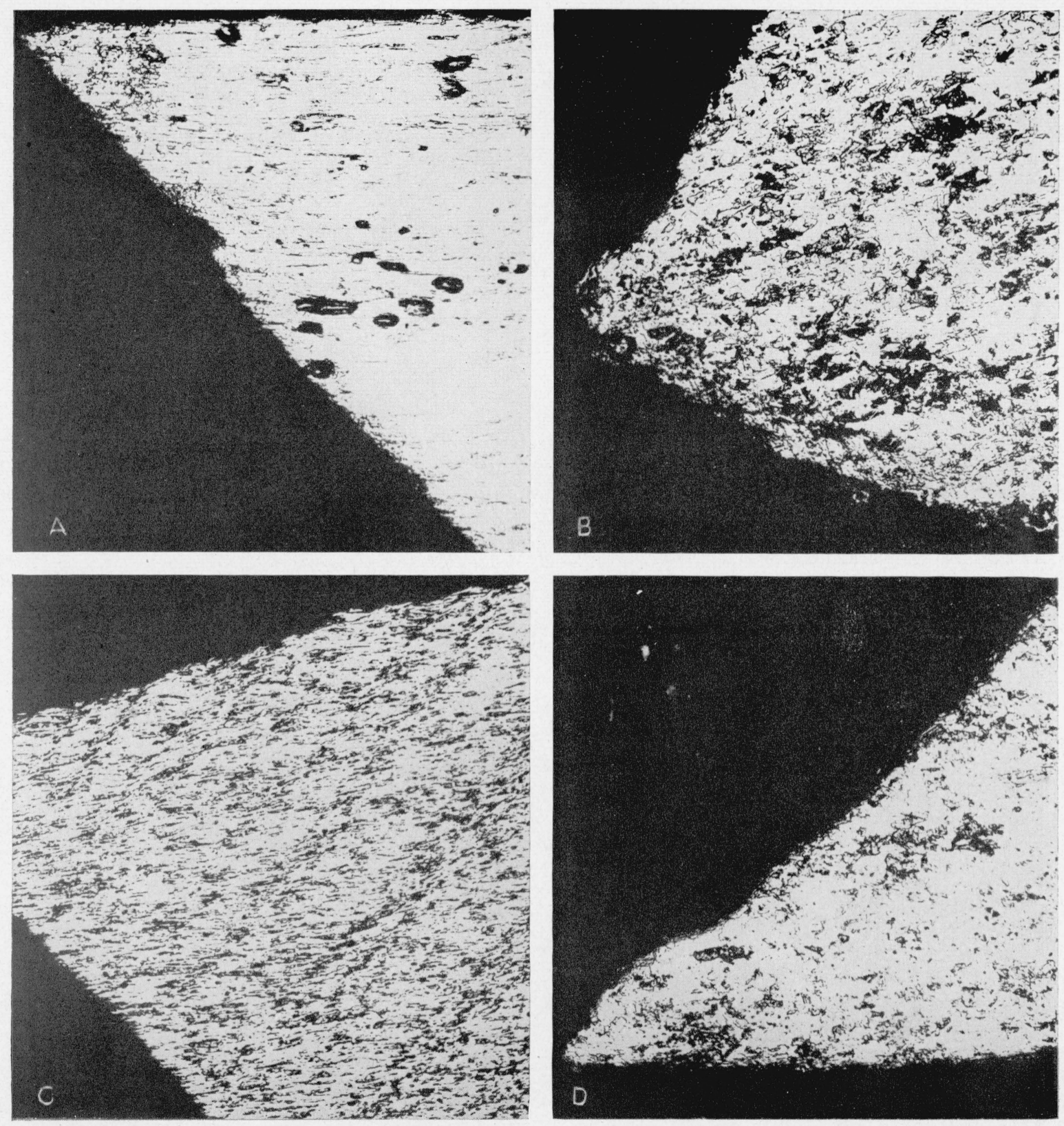

FIGURE 13. Structures at the surfaces of specimens of cold-drawn copper fractured in tension at room temperature.

Longitudinal sections at the intersection of the outer (original) and fracture surfaces. Etched in equal parts of $\mathrm{NH}_{4} \mathrm{OH}$ and $\mathrm{H}_{2} \mathrm{O}_{2}(3 \%)$. $\times 100$.

\begin{tabular}{|c|c|c|c|c|}
\hline & \multirow[b]{2}{*}{ Initial condition } & \multicolumn{3}{|c|}{ Creep test } \\
\hline & & $\begin{array}{c}\text { Temper- } \\
\text { ature }\end{array}$ & Rate & $\begin{array}{l}\text { Plastic } \\
\text { exten- } \\
\text { sion }\end{array}$ \\
\hline $\begin{array}{l}A_{\ldots} \ldots \\
B_{\ldots}\end{array}$ & $\begin{array}{l}\text { Cold-drawn } 40 \% \text { reduction in area } \\
\text { do }\end{array}$ & $\left\{\begin{array}{c}{ }^{\circ} \mathrm{F} \\
250 \\
110 \\
300\end{array}\right.$ & $\begin{array}{c}\% / 1,000 \mathrm{hr} \\
0.20 \\
.63 \\
200+\end{array}$ & $\begin{array}{l}\% \\
0.73 \\
.73 \\
2.8\end{array}$ \\
\hline $\begin{array}{l}\mathrm{C} \\
\mathrm{D}-\ldots\end{array}$ & $\begin{array}{l}\text { Cold-drawn } 34 \% \text { reduction in area } \\
\text { Cold-drawn } 70 \% \text { reduction in area- }\end{array}$ & None & $\begin{array}{c}\text { None } \\
\text { do }\end{array}$ & $\begin{array}{l}\text { None. } \\
\text { Do. }\end{array}$ \\
\hline
\end{tabular}



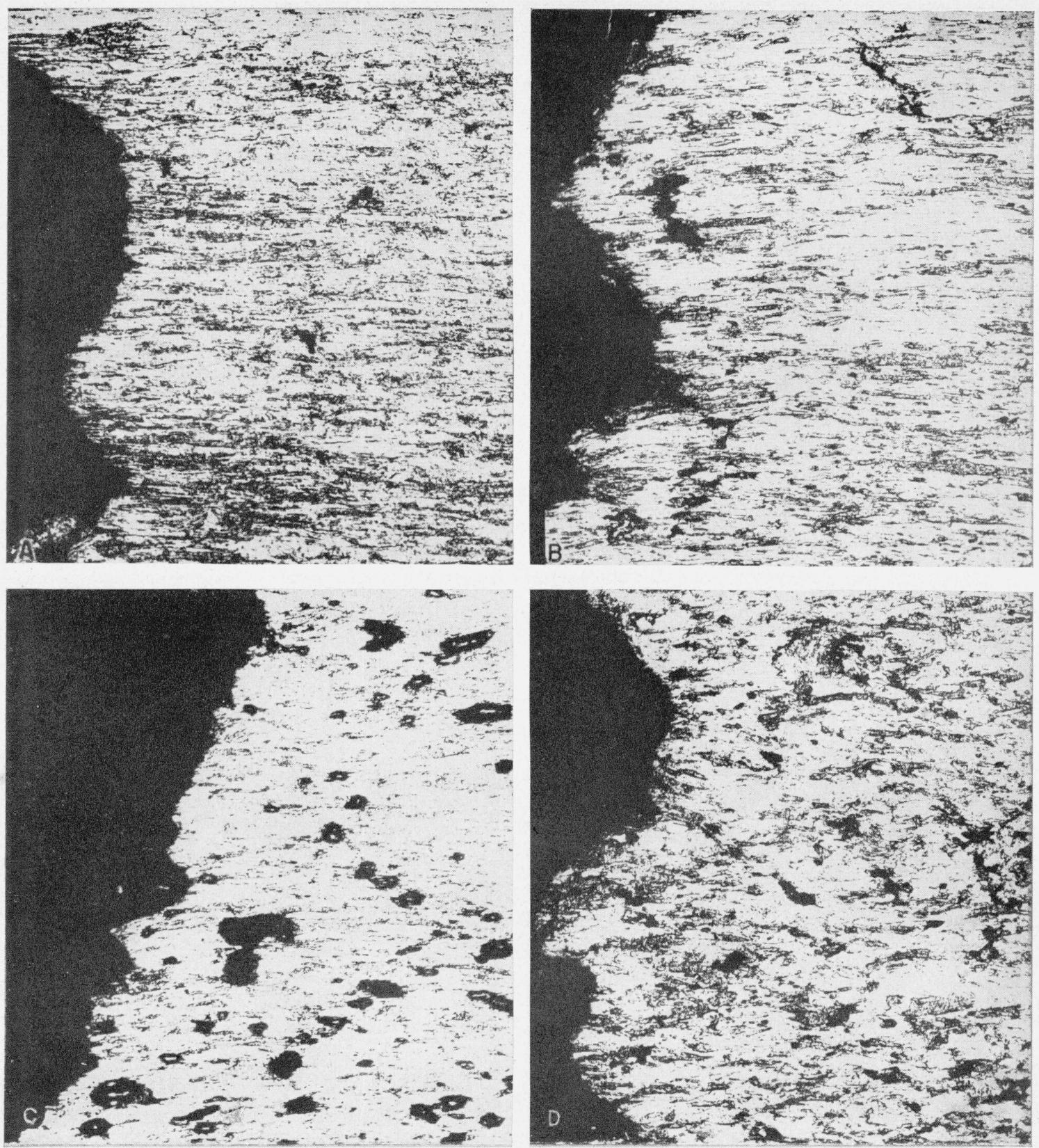

FIGURE 14. Structures at the axis of specimens of annealed copper fractured in tension at room temperature.

Longitudinal sections at the intersection of the axis and fracture surface. Etched in equal parts of $\mathrm{NH}_{4} \mathrm{OH}$ and $\mathrm{H}_{2} \mathrm{O}_{2}(3 \%), \times 100$

\begin{tabular}{|c|c|c|c|c|}
\hline & \multirow{2}{*}{ Initial condition } & \multicolumn{3}{|c|}{ Creep test } \\
\hline & & $\begin{array}{l}\text { Tem- } \\
\text { pera- } \\
\text { ture }\end{array}$ & Rate & $\begin{array}{l}\text { Plastic } \\
\text { exten- } \\
\text { sion }\end{array}$ \\
\hline $\begin{array}{l}\mathrm{A}-\ldots . \\
\mathrm{B}_{-. .}\end{array}$ & Annealed $800^{\circ} \mathrm{F}-$ & $\begin{array}{l}{ }^{\circ} \mathrm{F} \\
110 \\
250\end{array}$ & $\begin{array}{c}\% / 1,000 \mathrm{hr} \\
2.75 \\
1.1\end{array}$ & $\begin{array}{r}\% \\
39.7 \\
7.0\end{array}$ \\
\hline $\begin{array}{l}\mathrm{C}_{-} \ldots \\
\mathrm{D}_{-}-. .\end{array}$ & $\begin{array}{l}\text { Annealed } 800^{\circ} \mathrm{F} \\
\text {. }\end{array}$ & $\begin{array}{l}250 \\
250\end{array}$ & $\begin{array}{l}1.04 \\
10.1\end{array}$ & $\begin{array}{l}23.1 \\
49.0\end{array}$ \\
\hline
\end{tabular}



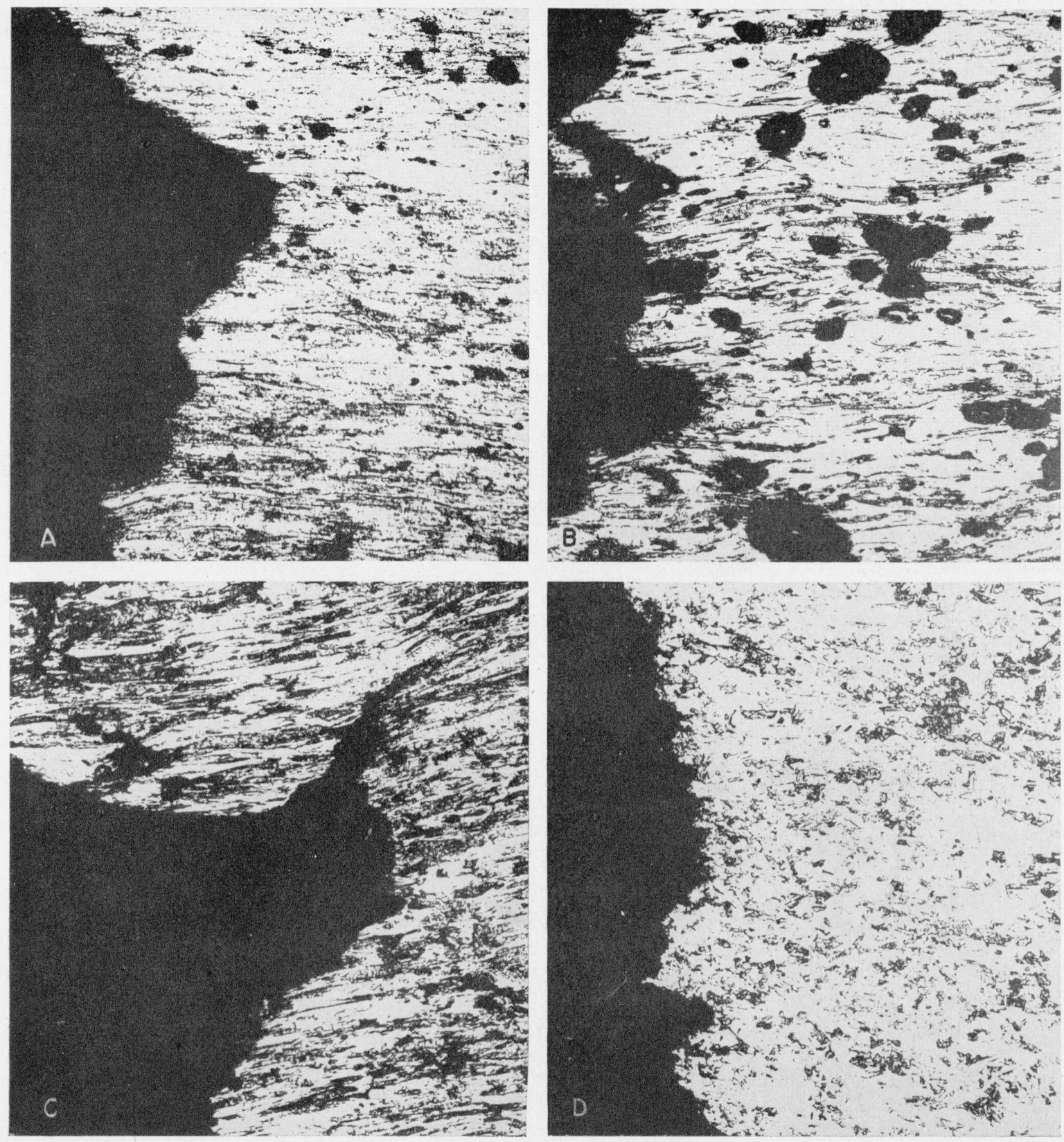

FIGURE 15. Structures at the axis of specimens of copper initially cold-drawn $40 \%$ reduction in area after fracturing in tension at room temperature.

Longitudinal sections at the intersection of the axis and fracture surface. Etched in equal parts of $\mathrm{NH}_{4} \mathrm{OH}$ and $\mathrm{H}_{2} \mathrm{O}_{2}(3 \%)$. $\times 100$.

\begin{tabular}{|c|c|c|c|}
\hline & \multicolumn{3}{|c|}{ Creep test } \\
\hline & $\begin{array}{l}\text { Tempera- } \\
\text { ture }\end{array}$ & Rate & $\begin{array}{c}\text { Plastic } \\
\text { extension }\end{array}$ \\
\hline $\begin{array}{l}\mathrm{A} \\
\mathrm{B} \\
\mathrm{C} \\
\mathrm{D}\end{array}$ & $\begin{array}{c}{ }^{\circ} F \\
\text { None } \\
250 \\
300 \\
\{110 \\
300\end{array}$ & $\begin{array}{c}\% / 1,000 h r . \\
\text { None } \\
0.20 \\
.36 \\
.63 \\
200+\end{array}$ & $\begin{array}{c}\% \\
\text { None } \\
0.730 \\
.98 \\
.73 \\
2.8\end{array}$ \\
\hline
\end{tabular}



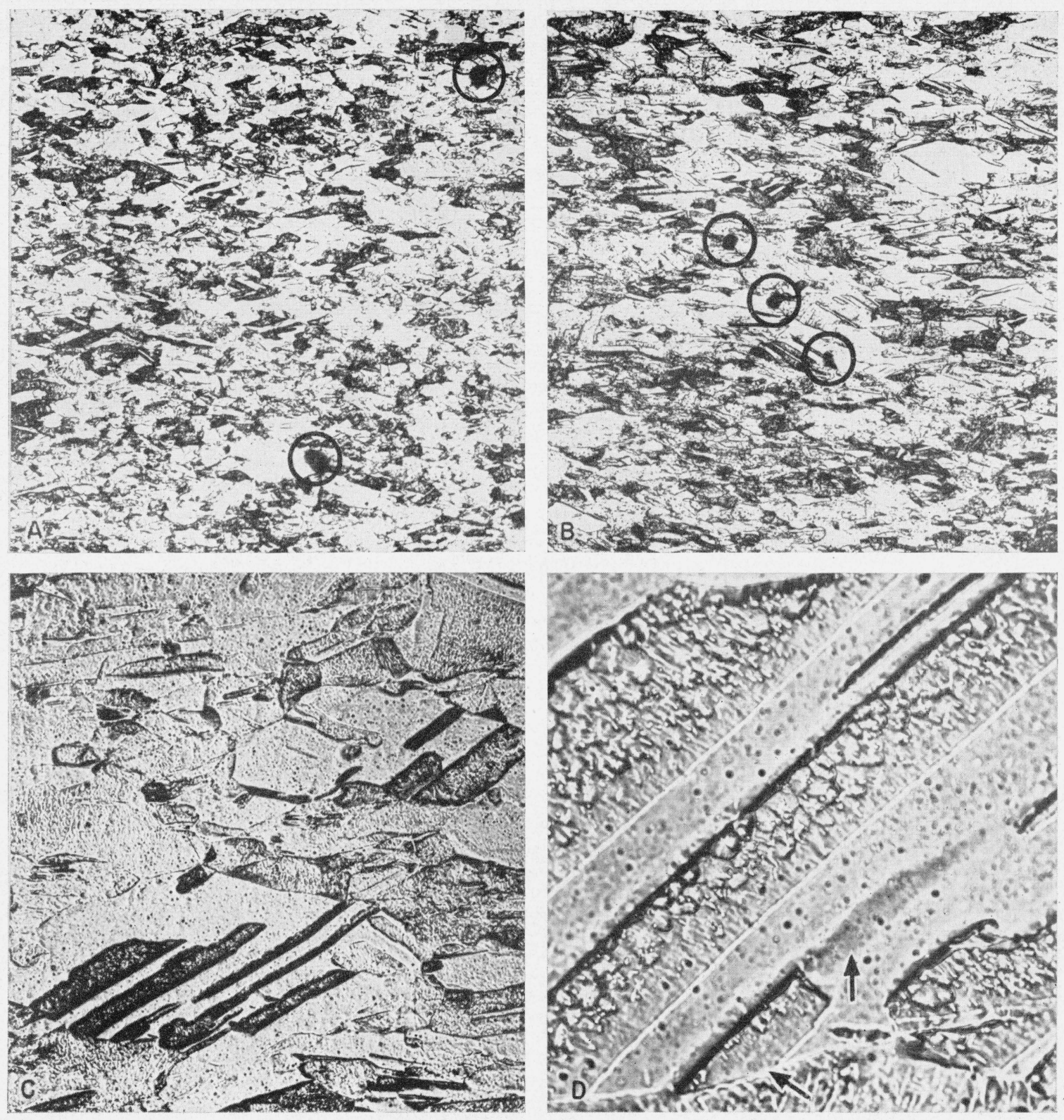

FIGURE 16. Structure in the un-necked region corresponding to the limit of uniform extension of specimens fractured in tension at room temperature.

Longitudinal sections near axis, etched in equal parts of $\mathrm{NH}_{4} \mathrm{OH}$ and $\mathrm{H}_{2} \mathrm{O}_{2}$ $(3 \%)$.

\begin{tabular}{|c|c|c|c|c|c|}
\hline & \multirow{2}{*}{ Initial condition } & \multicolumn{3}{|c|}{ Creep test } & \multirow{2}{*}{$\begin{array}{l}\text { Magnifi } \\
\text { cation }\end{array}$} \\
\hline & & $\begin{array}{l}\text { Tem- } \\
\text { pera- } \\
\text { ture }\end{array}$ & Rate & $\begin{array}{c}\text { Plastic } \\
\text { extension }\end{array}$ & \\
\hline $\begin{array}{l}\text { A.- } \\
\text { B.- }\end{array}$ & $\begin{array}{l}\text { Annealed } 800^{\circ} \mathrm{F} \\
\text { Cold-drawn } 40 \% \text { reduc- }\end{array}$ & $\begin{array}{l}{ }^{\circ} \mathrm{F} . \\
250 \\
250\end{array}$ & $\begin{array}{l}\% / 1,000 \mathrm{hr} . \\
1.04 \\
0.20\end{array}$ & $\begin{array}{c}\% \\
23.1 \\
0.73\end{array}$ & $\begin{array}{l}\times 100 \\
\times 100\end{array}$ \\
\hline C.. & $\begin{array}{l}\text { Cold-drawn } 70 \% \text { reduc- } \\
\text { tion in area; annealed } \\
1300^{\circ} \mathrm{F} \text {. }\end{array}$ & None.. & None... & $\begin{array}{c}\text { None.... } \\
\text { _... do }\end{array}$ & $\begin{array}{l}\times 100 . \\
\times 500\end{array}$ \\
\hline
\end{tabular}



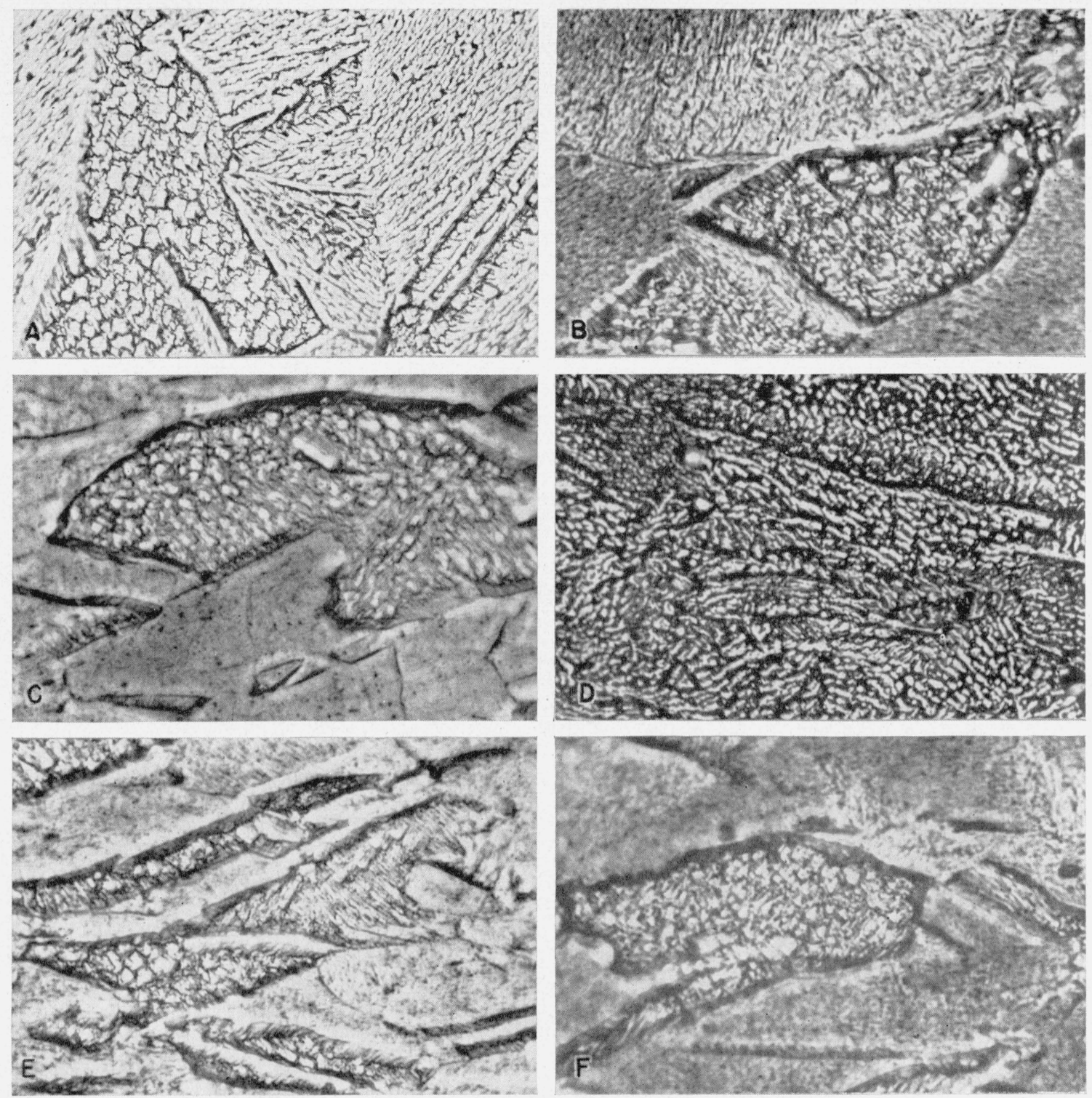

FIGURE 17. Effect of testing conditions on the structure of copper.

Longitudinal sections near axis, etched in 3 parts of glacial acetic acid, 6 parts of nitric acid (conc.) and 1 part of ethylene glycol. $\times 750$

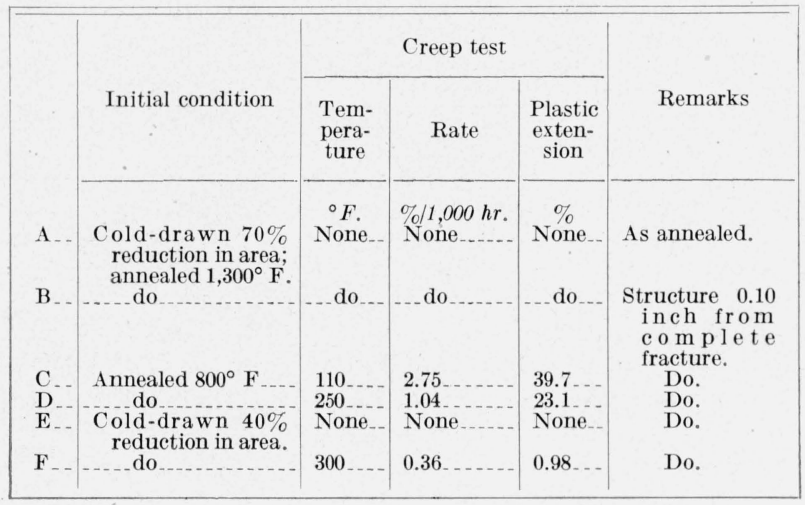




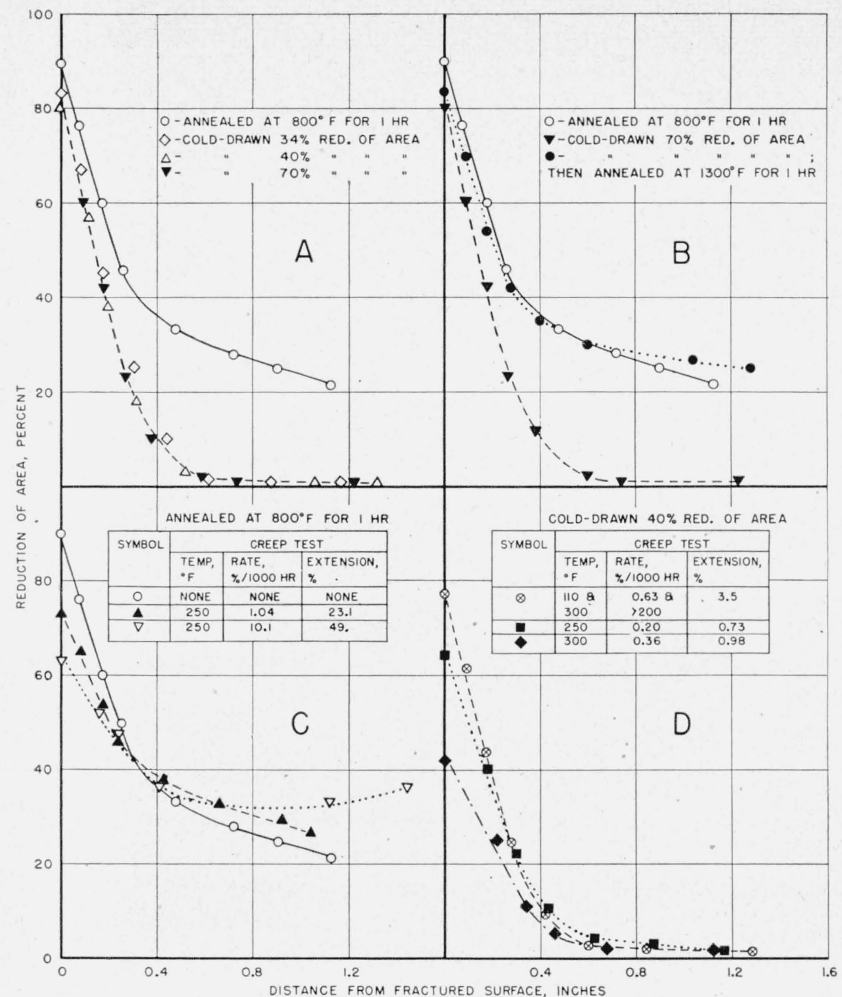

FiguRE 18. Effect of prestraining on the necking characteristics of specimens fractured in tension at room temperature.

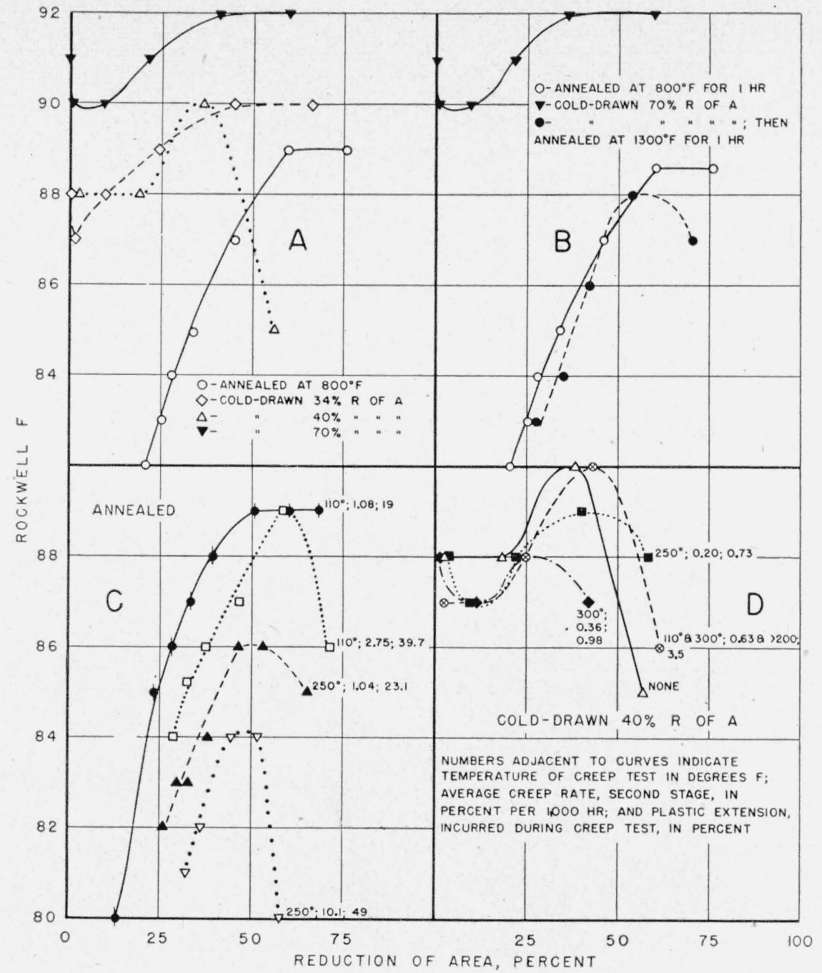

FIGURE 19. Effect of prestraining on the hardness-reduction of area relation of specimens fractured in tension at room temperature.

Washington, March 31, 1952. 